\title{
Remediation of Pesticides by Microalgae as Feasible Approach in Agriculture: Bibliometric Strategies
}

\author{
Gayathiri Verasoundarapandian ${ }^{1}{ }^{\mathbb{D}}$, Zheng Syuen Lim ${ }^{1}{ }^{\mathbb{D}}$, Syahirah Batrisyia Mohamed Radziff ${ }^{1}$, \\ Siti Hajar Taufik ${ }^{1}{ }^{\circ}$, Nurul Aini Puasa ${ }^{1}$, Noor Azmi Shaharuddin ${ }^{1,2}$, Faradina Merican ${ }^{3}$, Chiew-Yen Wong ${ }^{4} \mathbb{D}^{(}$, \\ Japareng Lalung ${ }^{5}($ i) and Siti Aqlima Ahmad $1,6, *$ (i)
}

1 Department of Biochemistry, Faculty of Biotechnology and Biomolecular Sciences, Universiti Putra Malaysia, Serdang 43400, Selangor, Malaysia; gayathiri1802@gmail.com (G.V.); syuenylim@gmail.com (Z.S.L.); syahirahbatrisyia@gmail.com (S.B.M.R.); hajartaufik21@gmail.com (S.H.T.); nurulainipuasa@gmail.com (N.A.P.); noorazmi@upm.edu.my (N.A.S.)

2 Institute of Plantation Studies, Universiti Putra Malaysia, Serdang 43400, Selangor, Malaysia

3 School of Biological Sciences, Universiti Sains Malaysia, Minden 11800, Pulau Pinang, Malaysia; faradina@usm.my

4 School of Health Sciences, International Medical University, Bukit Jalil, Kuala Lumpur 57000, Selangor, Malaysia; WongChiewYen@imu.edu.my

5 School of Industrial Technology, Universiti Sains Malaysia, Minden 11800, Pulau Pinang, Malaysia; japareng@usm.my

6 Laboratory of Bioresource Management, Institute of Tropical Forestry and Forest Products (INTROP), Universiti Putra Malaysia, Serdang 43400, Selangor, Malaysia

* Correspondence: aqlima@upm.edu.my

Citation: Verasoundarapandian, G.; Lim, Z.S.; Radziff, S.B.M.; Taufik, S.H.; Puasa, N.A.; Shaharuddin, N.A.; Merican, F.; Wong, C.-Y.; Lalung, J.; Ahmad, S.A. Remediation of Pesticides by Microalgae as Feasible Approach in Agriculture: Bibliometric Strategies. Agronomy 2022, 12, 117. https://doi.org/ 10.3390/agronomy 12010117

Academic Editor: Pankaj Bhatt

Received: 29 September 2021

Accepted: 6 December 2021

Published: 4 January 2022

Publisher's Note: MDPI stays neutral with regard to jurisdictional claims in published maps and institutional affiliations.

Copyright: (c) 2022 by the authors. Licensee MDPI, Basel, Switzerland. This article is an open access article distributed under the terms and conditions of the Creative Commons Attribution (CC BY) license (https:// creativecommons.org/licenses/by/ $4.0 /)$.

\begin{abstract}
Pesticide treatment dramatically reduces crop loss and enhances agricultural productivity, promoting global food security and economic growth. However, owing to high accrual and persistent tendency, pesticides could create significant ecological consequences when used often. Lately, the perspective has transitioned to implementing biological material, environmentally sustainable, and economical strategies via bioremediation approaches to eradicate pesticides contaminations. Microalgae were regarded as a prominent option for the detoxification of such hazardous contaminants. Sustainable application and remediation strategies of pesticides pollutants in the agriculture system by microalgae from the past studies, and recent advancements were integrated into this review. Bibliometric strategies to enhance the research advancements in pesticide bioremediation by microalgae between 2010 and 2020 were implemented through critical comparative analysis of documents from Scopus and PubMed databases. As a result, this study identified a growing annual research trend from 1994 to 2020 ( $n$ Scopus > nPubMed). Global production of pesticide remediation by microalgae demonstrated significant contributions from India (23.8\%) and China (16.7\%). The author's keyword clustering was visualized using bibliometric software (VOSviewer), which revealed the strongest network formed by "microalgae", "bioremediation", "biodegradation", "cyanobacteria”, "wastewater", and "pesticide" as significant to the research topic. Hence, this bibliometric review will facilitate the future roadmap for many scholars and authors who were drawing attention to the burgeoning research on bioremediation of pesticides to counteract environmental impacts while maintaining food sustainability.
\end{abstract}

Keywords: bioremediation; pesticides; microalgae; agriculture; bibliometric analysis

\section{Introduction}

The use of pesticides is expanding daily in tandem with increased urbanization and concomitant agricultural intensification. According to the World Health Organization, pesticides are chemical compounds that control pests. Pesticide formulations typically include both active and inert components. The active compound targets and kills the pest, whilst the inert component boosts the active component's efficacy [1]. The Green Revolution 
of the 1960s and 1970s, which remarkably increased agricultural yields, backfired with detrimental environmental issues from the poorly managed irrigation and overuse of pesticides [2,3]. Although pesticides have high potential, excessive use of these pesticides created grave concerns about human and environmental health. Pesticides could be released into the air, absorbed into the soil, or ingested by plants and animals. The environmental conditions as well as the physical and chemical characteristics determines the fate of pesticide; soil mobility, solubility in water, and volatility in the air [4]. Direct application of pesticides on agri-crops due to their rapid bioaccumulation in nontarget organisms can lead to soil fertility and water system contamination through soil leaching. Furthermore, water pollution is by far the most critical issue contributed by agricultural run-off. Nitrate was recognized as one of the most common sources of agricultural pollution leading to eutrophication [5]. Since then, the European Drinking Water Directive 98/83/EC established a single pesticide threshold of $0.1 \mu \mathrm{g} / \mathrm{L}$ and total pesticides of $0.5 \mu \mathrm{g} / \mathrm{L}$ in human drinking water [6]. Therefore, agricultural pollutants need to be remediated to prevent adverse effects on humans and animals.

Bioremediation can be a feasible alternative in the instance of pesticide contamination. Microorganisms are adapted in bioremediation to eliminate or convert hazardous chemicals into nontoxic compounds [7-9]. It is suggested to be an economical and reliable alternative. The current review attempts to explore the emerging pesticide contaminations and their usage and environmental implications, as well as applications of microalgae as remediating agents and their mechanisms of action for effective removal and treatment of pesticides or derivates in agriculture. To date, the contributions of microalgae in their entirety were only examined systematically and visualized in very limited number of studies [9-11]. Even so, an aspiring researcher could not go through a handful of studies to comprehend the advances in a topic or field. There is still a scarcity of thorough assessments concentrating on the fundamental background on bioremediation of pesticides by microalgae research throughout the world. Therefore, bibliometric analysis was performed as a comprehensive tool for accomplishing this goal.

The Scopus and PubMed scholarly databases were used to extract research documents and assess the present our outlook on utilizing microalgae as a feasible approach for remediating pesticides pollution. The data will uncover the core knowledge in this field, as well as statistically visualize (VOSviewer and DataWrapper) and evaluate the most relevant study pathways. Systematic literature reviews centered on bibliometric analyses offer additional insight into annual publication trends, national contributions, and keyword cooccurrence cluster mapping. The significance of the work emphasizes the link between keywords and related terms, forming clusters that draw the key research interest, and thus highlighting topics that are emerging and require additional investigation.

\section{Application of Pesticides in Agriculture}

Agriculture underpins the livelihoods of over 2.5 billion people, and the demands for agricultural production are constantly growing. By 2030, China would require a total of almost 100 billion kilograms more grain than the current production [12]. The agricultural sector is particularly vulnerable to natural disasters and hazards. In response to that, the economy of low-income countries (LIC) and lower-middle-income countries (LMIC) that rely heavily on agriculture were hit the hardest, especially since 2020 in the aftermath of COVID-19. The International Food Policy Research predicts a 25\% reduction in agricultureand food-related commodity exports due to the underlying food insecurity issue, which heightened since the onset of COVID-19 [13]. While the loss in crop production due to natural disasters is inevitable, the impact from crop and livestock pests, diseases, and infestation can be alleviated with the help of pesticides. Pesticides were used chiefly to improve the quality and quantity of crops and livestock and increasing yield and revenue. World annual pesticide consumption in 2019 recorded a high at 4.19 million tons [14]. China alone contributed 1.41 million tons of consumption, followed by the United States, Brazil, Argentina, and Canada. The advances in pesticide application long replaced the 
traditional mechanical control of weeds using mule- or horse-drawn and hand hoeing, thus boosting the overall farming efficiency. Weed and pest management generates both primary and secondary benefits. The primary benefit is the direct gains from use, such as higher crop yield and better crop quality. Secondary benefits are less immediate or less obvious, which is a cumulative result from many primary benefits relative to food security and national and global economic benefits [15].

Pesticides can be classified by the target organisms (the types of pests they control), and the chemical structures or physical states (solid, liquid and gas). Pesticides are most recognized as insecticides, herbicides, rodenticides and fungicides. However, according to US Environmental Protection Agency (EPA), there are 24 types of pesticides on the market based on their target organisms. Amongst the wide range of pesticides, the herbicide is the most commonly used, with a consumption percentage of $40-50 \%$, which signifies its extensive application to kill weeds and unwanted plant species [14]. Herbicides can be categorized into contact and systemic herbicides, determined by their toxic mode of action and their application method. Contact herbicides usually provide an instant effect on the application site upon contact, whereas systemic herbicides transport internally to other parts of the plant through absorption of plant tissues [16]. Based on their modes of action, herbicides can be grouped into growth regulators, amino acid synthesis inhibitors, photosynthetic inhibitors, lipid synthesis inhibitors, seedling root or shoot growth inhibitors, cell membrane disrupters, and pigment inhibitors [17].

An example of a widely used herbicide, namely, 2,4-dichlorophenoxyacetic acid (2,4D), is the first herbicide developed commercially for broadleaf control. It is sometimes referred to as synthetic auxin, and thus acts as a plant growth regulator herbicide [18]. At low doses, 2,4-D functions as a plant growth promoter, whereas at high doses, it induces uncontrollable growth, leads to stems curling, cupped leaves, and ultimately, plant death. Jyothi [19] reported the positive effect of the application of 2,4-D in stimulating the growth and synthesis of cellular metabolites at low doses $(200 \mu \mathrm{g} / \mathrm{mL})$ in the cyanobacterium, Synechococcus aeruginosus. In contrast, a high dose (i.e., 500, 800, or $1000 \mu \mathrm{g} / \mathrm{mL}$ ) poses a lethal effect on growth of S. aeruginosus. Another main toxic effect caused by 2,4-D is the production of reactive oxygen species (ROS) due to the activation of specific enzymes such as xanthine oxido-reductase and acyl-CoA oxidase [20]. In response to the overproduction of ROS, young leaves will proceed into the epinasty development while the adult tissues will enter the senescence process. Pre- and postharvest application of 2,4-D in the citrus fruit industry are also evident in reducing premature fruit drop, stem-end rot and prolonging the fruit shelf life when in cooperating with other fungicides [21,22].

Aside from the major classes of herbicide aforementioned, organic arsenicals herbicide (e.g., DSMA and MSMA) is poorly understood regarding its mode of action, but it is known to exhibit a similar cell membrane disruption effect on weeds. An antagonistic effect was reported on several broadleaves and grass weeds in the combined application of MSMA with glyphosate and glufosinate herbicides [23]. This is due to the disruption of cell membrane, which impedes the absorption and translocation of systemic herbicides. Thus, the application of organic arsenicals with systemic herbicides in a mixture tank is not recommended. A few more commonly used pesticides with their application and effects on target organisms are listed in Table 1. The use of pesticides in modern agriculture ranges widely from crops production to livestock rearing, marking its indispensable role in the industry. Using an estimation model, the impact of pesticide reduction was computed and quantified in crop yield loss. A 50\% reduction in pesticide use would result in the winter wheat yield loss of $5-13 \%$ of the yield obtained compared to the current pesticide use in France $\left(0.4-0.9 \mathrm{t} \mathrm{ha}^{-1}\right)$. In comparison, the potential grain yield loss for zero-pesticide systems varied from $2-2.3 \mathrm{tha}^{-1}$ [24].

To counteract to global warming issue, the application of pesticides in the future climate condition has gained global attention because even the slightest increase in herbicide tolerance will be a future liability. Most of the previous simulation studies report a reduced efficacy of herbicides under high $\mathrm{CO}_{2}$ concentration [25-27]. At the same time, 
a neutral effect of elevated $\mathrm{CO}_{2}$ concentration on herbicide efficacy against weeds has also been reported in rare cases [25,28-30]. Jabran and Doğan [28] showed that the activity of glyphosate was not impacted despite the positively stimulated weed growth at $450 \mathrm{ppm} \mathrm{CO}$ treatment. The result is corroborated by Bajwa et al. [29], who further demonstrated this finding. The overall efficacy of glyphosate was not significantly impacted at the end of the 21 days of their observation period. The recommended dosage of glyphosate application (1034 $\mathrm{g}^{\text {ae }} \mathrm{ha}^{-1}$ ) gave $100 \%$ biomass reduction under ambient and elevated $\mathrm{CO}_{2}$ environments for S. cannabina weed [30]. On the other hand, in the experiment testing on an extensive range of weeds (vine, herb, shrub and grass species) under elevated atmospheric $\mathrm{CO}_{2}$ concentration (550 ppm), weed species demonstrated different responses and tolerance levels towards glyphosate application [25]. Fast-growing plants and vines showed the highest resistance, while $\mathrm{C} 3$ grasses tended to be the most sensitive towards herbicide application. These experiments proved an equally effective glyphosate activity at $\mathrm{CO}_{2}$ concentration slightly higher than the ambient atmospheric level (380 ppm). However, further enrichment of $\mathrm{CO}_{2}$ (above $600 \mathrm{ppm}$ ) was reported to diminish the glyphosate efficacy [26,27]. No generalization of the effect of elevated $\mathrm{CO}_{2}$ levels on herbicide efficacy was concluded, but the susceptibility of weeds towards herbicide application is species-specific. Although the underlying causal mechanism of the decline is unclear, various studies attribute the phenomenon to the increase of weeds growth (biomass) and morphological adaptation (leaf thickness and wax deposition), which lead to slowed translocation of herbicide [31,32]. Nevertheless, glyphosate application is still highly damaging, reducing the growth and flowering of plants across all levels of $\mathrm{CO}_{2}$ treatments, albeit at a reduced rate.

Table 1. Example of pesticides from three main categories-herbicides, insecticides, and fungicide with their target organism and mode of action.

\begin{tabular}{|c|c|c|c|c|c|c|}
\hline $\begin{array}{l}\text { Active } \\
\text { Ingredient }\end{array}$ & $\begin{array}{l}\text { Type of } \\
\text { Pesticide }\end{array}$ & $\begin{array}{l}\text { Target } \\
\text { Organism }\end{array}$ & Mode Action & $\begin{array}{l}\text { Agricultural } \\
\text { Application }\end{array}$ & $\begin{array}{l}\text { Availability } \\
\text { Status }\end{array}$ & References \\
\hline & & & \multicolumn{4}{|l|}{ Herbicides } \\
\hline $\begin{array}{l}\text { 2,4-D } \\
\text { (2,4-Dichloro- } \\
\text { phenoxyacetic } \\
\text { acid) }\end{array}$ & $\begin{array}{l}\text { Chlorophenoxy } \\
\text { herbicide } \\
\text { (systemic } \\
\text { herbicide) }\end{array}$ & $\begin{array}{l}\text { Broadleaf } \\
\text { weeds and } \\
\text { evasive weeds } \\
\text { in the aquatic } \\
\text { environment }\end{array}$ & $\begin{array}{l}\text { Acts as a growth } \\
\text { regulator. Induce } \\
\text { uncontrolled cell } \\
\text { division in vascular } \\
\text { tissue due to abnormal } \\
\text { increases in cell wall } \\
\text { plasticity, biosynthesis of } \\
\text { proteins, and production } \\
\text { of ethylene }\end{array}$ & $\begin{array}{l}\text { Field corn, } \\
\text { soybean, spring } \\
\text { wheat, } \\
\text { hazelnuts, } \\
\text { sugarcane, } \\
\text { cereals }\end{array}$ & Current & {$[33,34]$} \\
\hline Glyphosate & $\begin{array}{l}\text { Organophosphate } \\
\text { herbicide and } \\
\text { desiccant } \\
\text { (systemic } \\
\text { herbicide) }\end{array}$ & $\begin{array}{l}\text { Annual and } \\
\text { perennial } \\
\text { weeds, } \\
\text { broadleaf } \\
\text { weeds and } \\
\text { grasses }\end{array}$ & $\begin{array}{l}\text { Disrupts the shikimic } \\
\text { acid pathway via } \\
\text { inhibition of } \\
\text { 5-enolpyruvylshikimate- } \\
\text { 3-phosphate } \\
\text { synthase. }\end{array}$ & $\begin{array}{l}\text { Fruits, } \\
\text { vegetables, } \\
\text { grains, legumes, } \\
\text { herbs, and } \\
\text { spices }\end{array}$ & Current & [35] \\
\hline $\begin{array}{l}\text { Dicamba } \\
\text { (3,6-dichloro-2- } \\
\text { methoxy- } \\
\text { benzoic } \\
\text { acid) }\end{array}$ & $\begin{array}{l}\text { Benzoic acid } \\
\text { herbicide } \\
\text { (systemic } \\
\text { herbicide) }\end{array}$ & $\begin{array}{l}\text { Annual and } \\
\text { perennial } \\
\text { broadleaf } \\
\text { weeds and } \\
\text { woody plants } \\
\text { (e.g., bedstraw, } \\
\text { buttercup, } \\
\text { pigweed) }\end{array}$ & $\begin{array}{l}\text { Acts as a growth } \\
\text { regulator. Induces } \\
\text { abnormal and } \\
\text { uncontrollable growth at } \\
\text { high dicamba } \\
\text { concentrations. }\end{array}$ & $\begin{array}{l}\text { Corn, cereals, } \\
\text { dicamba } \\
\text { tolerant (DT) } \\
\text { soybeans and } \\
\text { cotton }\end{array}$ & Current & {$[36,37]$} \\
\hline
\end{tabular}


Table 1. Cont.

\begin{tabular}{|c|c|c|c|c|c|c|}
\hline $\begin{array}{l}\text { Active } \\
\text { Ingredient }\end{array}$ & $\begin{array}{l}\text { Type of } \\
\text { Pesticide }\end{array}$ & $\begin{array}{l}\text { Target } \\
\text { Organism }\end{array}$ & Mode Action & $\begin{array}{l}\text { Agricultural } \\
\text { Application }\end{array}$ & $\begin{array}{l}\text { Availability } \\
\text { Status }\end{array}$ & References \\
\hline Atrazine & $\begin{array}{l}\text { Triazine } \\
\text { herbicide } \\
\text { (systemic } \\
\text { herbicide) }\end{array}$ & $\begin{array}{l}\text { Broadleaf } \\
\text { weeds and } \\
\text { grasses (e.g., } \\
\text { morning glory, } \\
\text { crabgrass, } \\
\text { barnyard grass) }\end{array}$ & $\begin{array}{l}\text { Competitive inhibition } \\
\text { for plastoquinone } \\
\text { binding leads to } \\
\text { inhibition of } \\
\text { photosynthesis. }\end{array}$ & $\begin{array}{l}\text { Corn, sorghum, } \\
\text { sugarcane }\end{array}$ & Current & [38] \\
\hline $\begin{array}{l}\text { Paraquat/ } \\
\text { paraquat } \\
\text { dichloride }\end{array}$ & $\begin{array}{l}\text { Bipyridinium } \\
\text { herbicide and } \\
\text { desiccant } \\
\text { (contact } \\
\text { herbicide) }\end{array}$ & $\begin{array}{l}\text { Broadleaf } \\
\text { weeds (e.g., } \\
\text { cocksfoot) and } \\
\text { grasses (e.g., } \\
\text { ryegrass, wild } \\
\text { oats, fescue } \\
\text { Yorkshire fog } \\
\text { grass) }\end{array}$ & $\begin{array}{l}\text { Inhibits photosynthesis } \\
\text { and disrupt cell } \\
\text { membranes, which } \\
\text { allows water to escape } \\
\text { leads to rapid } \\
\text { desiccation. }\end{array}$ & $\begin{array}{l}\text { Beans and peas, } \\
\text { cotton, maize, } \\
\text { rubber, tomato, } \\
\text { citrus orchards, } \\
\text { vineyards }\end{array}$ & $\begin{array}{l}\text { Banned in } \\
\text { the } \\
\text { European } \\
\text { Union } \\
\text { nations, } \\
\text { China, and } \\
\text { Thailand }\end{array}$ & [39] \\
\hline $\begin{array}{l}\text { Monosodium } \\
\text { methanearson- } \\
\text { ate (MSMA) }\end{array}$ & $\begin{array}{l}\text { Organic } \\
\text { arsenical } \\
\text { herbicide } \\
\text { (contact } \\
\text { herbicide) }\end{array}$ & $\begin{array}{l}\text { Broadleaf weed, } \\
\text { grasses and } \\
\text { sedges }\end{array}$ & $\begin{array}{l}\text { Mode of action is not } \\
\text { known. The rapid } \\
\text { desiccation of plant } \\
\text { suggests cell membrane } \\
\text { destruction. }\end{array}$ & Cotton & $\begin{array}{l}\text { Severely } \\
\text { restricted. } \\
\text { Not } \\
\text { permitted } \\
\text { for other } \\
\text { agricultural } \\
\text { crops }\end{array}$ & {$[33,40]$} \\
\hline \multicolumn{7}{|c|}{ Insecticides } \\
\hline Chlorpyrifos & $\begin{array}{l}\text { Organophosphate } \\
\text { insecticide, } \\
\text { acaricide and } \\
\text { miticide }\end{array}$ & $\begin{array}{l}\text { Foliage and } \\
\text { soil-borne } \\
\text { insect pests } \\
\text { (e.g., scale, } \\
\text { armyworm, flea } \\
\text { beetles, fire } \\
\text { ants) }\end{array}$ & $\begin{array}{l}\text { Disrupts the nervous } \\
\text { system by inhibiting } \\
\text { acetylcholinesterase. }\end{array}$ & $\begin{array}{l}\text { Food crops (e.g., } \\
\text { cereals, cotton, } \\
\text { fruits, tomatoes, } \\
\text { nuts, } \\
\text { vegetables) and } \\
\text { livestock }\end{array}$ & Current & {$[33,40]$} \\
\hline Malathion & $\begin{array}{l}\text { Organophosphate } \\
\text { insecticide and } \\
\text { acaricide }\end{array}$ & $\begin{array}{l}\text { Insect pests } \\
\text { (e.g., aphids, } \\
\text { leafhoppers, } \\
\text { Japanese } \\
\text { beetles) }\end{array}$ & $\begin{array}{l}\text { Disrupts the nervous } \\
\text { system by inhibiting } \\
\text { acetylcholinesterase. }\end{array}$ & $\begin{array}{l}\text { Food, feed, and } \\
\text { ornamental } \\
\text { crops }\end{array}$ & Current & [41] \\
\hline Tetrachlorvinphos & $\begin{array}{l}\text { Organophosphate } \\
\text { insecticide and } \\
\text { acaricide }\end{array}$ & $\begin{array}{l}\text { Insect pests } \\
\text { (e.g., fleas, ticks, } \\
\text { flies, lice, insect } \\
\text { larvae) }\end{array}$ & $\begin{array}{l}\text { Disrupts the nervous } \\
\text { system by inhibiting } \\
\text { acetylcholinesterase. }\end{array}$ & $\begin{array}{l}\text { Poultry } \\
\text { (applied } \\
\text { dermal), horses, } \\
\text { cattle, goats, } \\
\text { and swine (oral } \\
\text { feed-through) }\end{array}$ & $\begin{array}{l}\text { Not } \\
\text { permitted } \\
\text { for food } \\
\text { crop use in } \\
\text { U.S. and } \\
\text { banned for } \\
\text { all uses in } \\
\text { the } \\
\text { European } \\
\text { Union }\end{array}$ & [42] \\
\hline Methomyl & $\begin{array}{l}\text { Carbamate } \\
\text { insecticide }\end{array}$ & $\begin{array}{l}\text { Foliage and } \\
\text { soil-borne } \\
\text { insect pests } \\
\text { (e.g., } \\
\text { lepidoptera, } \\
\text { coleoptera, } \\
\text { diptera) }\end{array}$ & $\begin{array}{l}\text { Disrupts the nervous } \\
\text { system by reversibly } \\
\text { inhibiting } \\
\text { acetylcholinesterase. }\end{array}$ & $\begin{array}{l}\text { Field } \\
\text { vegetables, } \\
\text { orchard crops, } \\
\text { cotton, sugar } \\
\text { beet }\end{array}$ & $\begin{array}{l}\text { Certain uses } \\
\text { in U.S. are } \\
\text { cancelled } \\
\text { (barley, oat } \\
\text { and rye) or } \\
\text { reduced } \\
\text { (wheat, corn } \\
\text { and lettuce) }\end{array}$ & {$[33,40]$} \\
\hline
\end{tabular}


Table 1. Cont.

\begin{tabular}{|c|c|c|c|c|c|c|}
\hline $\begin{array}{l}\text { Active } \\
\text { Ingredient }\end{array}$ & $\begin{array}{l}\text { Type of } \\
\text { Pesticide }\end{array}$ & $\begin{array}{l}\text { Target } \\
\text { Organism }\end{array}$ & Mode Action & $\begin{array}{l}\text { Agricultural } \\
\text { Application }\end{array}$ & $\begin{array}{l}\text { Availability } \\
\text { Status }\end{array}$ & References \\
\hline Carbofuran & $\begin{array}{l}\text { Carbamate } \\
\text { insecticide, } \\
\text { nematicide and } \\
\text { miticide }\end{array}$ & $\begin{array}{l}\text { Soil insect and } \\
\text { nematode (e.g., } \\
\text { corn } \\
\text { rootworms, } \\
\text { spider mites, } \\
\text { nematodes,) }\end{array}$ & $\begin{array}{l}\text { Disrupts the nervous } \\
\text { system by reversibly } \\
\text { inhibiting } \\
\text { acetylcholinesterase. }\end{array}$ & $\begin{array}{l}\text { Potatoes, rice, } \\
\text { citrus fruits, } \\
\text { vegetables, } \\
\text { cotton, alfalfa }\end{array}$ & $\begin{array}{l}\text { Banned in } \\
\text { many } \\
\text { countries }\end{array}$ & [40] \\
\hline Cypermethrin & $\begin{array}{l}\text { Synthetic } \\
\text { pyrethroid } \\
\text { insecticide }\end{array}$ & $\begin{array}{l}\text { Insect pests } \\
\text { (e.g., pod } \\
\text { midge, yellow } \\
\text { cereal fly, } \\
\text { blossom } \\
\text { beetles) }\end{array}$ & $\begin{array}{l}\text { Disrupts the nervous } \\
\text { system, which prolongs } \\
\text { the opening of the } \\
\text { sodium channel leading } \\
\text { to hyperexcitation. }\end{array}$ & $\begin{array}{l}\text { Cereals, peas } \\
\text { and beans, } \\
\text { oilseed rape, } \\
\text { potatoes }\end{array}$ & Current & [43] \\
\hline \multirow[t]{2}{*}{ Imidacloprid } & $\begin{array}{l}\text { neonicotinoid } \\
\text { insecticide }\end{array}$ & $\begin{array}{l}\text { Sucking and } \\
\text { soil insects (e.g., } \\
\text { plant hoppers, } \\
\text { aphids, } \\
\text { termites, } \\
\text { craneflies, } \\
\text { crickets) }\end{array}$ & $\begin{array}{l}\text { Interferes } \\
\text { neurotransmission by } \\
\text { postsynaptic antagonism } \\
\text { of nicotinic acetylcholine } \\
\text { receptors. }\end{array}$ & $\begin{array}{l}\text { Rice, cereals, } \\
\text { maize, potatoes, } \\
\text { sugar beet }\end{array}$ & Current & [44] \\
\hline & & & Fungicide & & & \\
\hline Mancozeb & $\begin{array}{l}\text { Dithiocarbamate } \\
\text { fungicide } \\
\text { (contact } \\
\text { fungicide) }\end{array}$ & $\begin{array}{l}\text { Fungal } \\
\text { pathogens } \\
\text { (potato blight, } \\
\text { leaf spot, scab) }\end{array}$ & $\begin{array}{l}\text { Prohibits chelating } \\
\text { properties, which } \\
\text { interferes with enzymes } \\
\text { containing sulfhydryl } \\
\text { group in fungi. }\end{array}$ & $\begin{array}{l}\text { Potatoes, fruit, } \\
\text { cotton, corn, } \\
\text { ornamental } \\
\text { shrubs }\end{array}$ & Current & {$[40,45]$} \\
\hline
\end{tabular}

\section{Environmental Impacts of Pesticides in Agriculture}

Extensive utilization of pesticides is needed to maximize crop production. Pesticides are known to be a chemical control for pests and also aid in preventing disease carriers. Generally, there are several mechanisms of pesticides degradation in the environment involving biological, chemical, and physical processes. Ideally, pesticides would be poisonous solely to the target organism, biodegradable, and leave no unpleasant residues on in the environment [46]. However, numerous reports on the negative impacts of the usage of pesticides on the environment are relatively significant [47-51]. The contamination of soil, ground, and surface water by various pesticides brought high toxicity effects to nontarget organisms, including humans. This is due to their low sorption and high period of degradation. Naturally, soil, microorganisms, plants, and animals are the biotic and abiotic elements directly in contact with pesticides.

Soil is the sole medium for agricultural production, which makes it crucially important to maintain. The soil functions that allow the soil to receive, retain, and recycle water, nutrients, and energy are referred to as soil quality [46]. Some pesticides promote microbial growth, while others have either a depressing effect or no effect at all [52]. Pesticides that alter the activities of soil microorganisms are likely to have a negative effect on soil nutritional quality and, as a result, have major ecological repercussions [46]. Fertilizers and pesticides have prolonged durability in the soil. Therefore, they are guaranteed to disrupt soil health by affecting the soil microflora and the livelihood of soil invertebrates $[53,54]$. In addition, soil fertility is affected not only by chemical and physical properties, but also biological properties of soil [55]. Soil bacteria converted or processed indigenous and added nutrients in soil to be readily available for plants [56]. However, the molecular signals that allow nitrogen-fixing bacteria to function are blocked by the usage of common insecticides, reducing microbes' ability to work properly. In the long run, the soils around 
treated plants might become depleted in nitrogen compounds. Hence, more fertilizer is required to obtain the same yield in which can be costly.

One of the subclasses of pesticides is insecticide. There is a type of insecticide known as a systemic insecticide which travels in the plant parts through water upstream [57]. Bees and other pollinators may be killed by systemic pesticides that poison pollen and nectar in the bloom [56]. Insects are important pollinators of flowering plants, with around 75\% of all agricultural plant species being entomophilous. Although many flowering plants may self-fertilize, most of them still rely on insect pollination to produce fertile seeds and sustain genetic variety [50]. Furthermore, the deposition of organic compounds or pesticides in soil exposes soil inhabitants directly. It raises the risk of exposure for other higher organisms through ingestion, which can have serious consequences for the soil ecology, waterways, plants, and human life [51]. Pesticides are currently posing a threat to human health and the environment, which has aroused concerns. Data from the last two decades revealed that certain pesticides induce neurological disorders and degenerative diseases, some affect prenatal growth and create congenital malformations, and others are carcinogenic to humans $[52,58-60]$.

\section{Mechanism of Action by Microalgae Remediation}

Microalgae are best suited for contaminant removal due to their high biosorption capabilities. The carbohydrate structure of the microalgal cell wall helps in the biosorption of toxic contaminants [9,61]. A study conducted by Hussein et al. [62], reported that biosorption occurs in removing pesticides such as atrazine, carbofuran, dimethoate, and simazine by living Chlorella vulgaris. Since the ouster removal occurs within a short time, it impossible for any action for active uptake and metabolization process to take place. In addition, physicochemical factors in such molecular size and structures also affect the biosorption process. The larger the algal particles, the greater the surface area available for pesticides to be biosorbed [63]. Hence, microalgae can effectively remove pesticides through biosorption. Microalgae are also able to accumulate toxic compounds. Their bioaccumulation ability depends on algal cell lipid content, which is affected by the growth condition and cell distribution [64,65]. Microorganisms can take up and remove pesticides either through the active or passive process. The active process requires energy-driven externally, whereas the passive process, involves direct interaction of physicochemical at chemical structures of the microorganism cell wall. The efficacy of pesticides removal by microalgae are heavily reliant on the chemical structure of the pesticide and the strain of microalgae employed. Microalgae can exploit pesticides, hydrocarbon, and cyanide as their carbon and nitrogen sources [9]. Bioaccumulation, biodegradation and biosorption are strategies in eliminating organic pollutants by microalgae (Table 2) [66].

\subsection{Biosorption}

In the biosorption process, the solid and liquid phases containing the dissolved or suspended species to be sorbed are involved [62]. Thus, it is defined as the attachment of potentially toxic pesticides elements to the surface of microalgae. Biosorption of pesticides by microalgae is considered a passive and metabolic-independent process that occurs faster than the bioaccumulation process. The unique cellular walls of microalgae are composed of sulfated polysaccharides that can increase the efficiency of pesticide adsorption from polluted water. In addition, the presence of polysaccharides, proteins, or some lipidcontaining functional groups such as amino, hydroxyl, carboxyl, and sulfate, can act as binding sites $[63,64]$. Properties of microalgae and surface-active groups are the factors that contribute to the adsorption efficiency [65]. Other factors that affect the removal adsorption of pesticide are related to structure of pesticide, $\mathrm{pH}$, temperature, salinity, nutrients, and light quality and strength [11]. 
Table 2. Remediation of pesticides by microalgae.

\begin{tabular}{|c|c|c|c|c|c|}
\hline Pesticides & Species of Algae & Mode of Action & $\begin{array}{l}\text { Concentration of } \\
\text { Pesticides Tested }\end{array}$ & $\begin{array}{c}\text { Removal } \\
\text { Efficiency (\%) }\end{array}$ & References \\
\hline$\alpha$-endosulfan & $\begin{array}{l}\text { Chlorococcum sp. } \\
\text { Scenedesmus sp. }\end{array}$ & Biodegradation & $1000 \mu \mathrm{g} / \mu \mathrm{L}$ & $65-75$ & [67] \\
\hline & Chlorella vulgaris & Biosorption & $10 \mu \mathrm{g} / \mathrm{L}$ & 96.29 & [6] \\
\hline Atrazine & Chlamydomonas mexicana & Biodegradation & $10 \mu \mathrm{g} / \mathrm{L}$ & 36 & [68] \\
\hline Bifenthrin & Parachlorella kessleri & Biodegradation & $5 \mathrm{mg} / \mathrm{L}$ & 85 & [48] \\
\hline Chlorpyrifos & Chlorella sorokiniana & Biosorption & $(100,300,500) \mathrm{ppm}$ & $(99.18,99.85,97.86)$ & [50] \\
\hline Diazinon & Chlorella vulgaris & Biodegradation & $20 \mathrm{mg} / \mathrm{L}$ & 94 & [69] \\
\hline Dimethomorph & $\begin{array}{l}\text { Scenedesmus obliquus } \\
\text { Scenedesmus quadricauda }\end{array}$ & Biodegradation & $600 \mu \mathrm{g} / \mathrm{L}$ & $\begin{array}{l}24 \\
15\end{array}$ & [70] \\
\hline Fluroxypyr & $\begin{array}{c}\text { Chlamydomonas } \\
\text { reinhardtii }\end{array}$ & Biodegradation & $0.5 \mathrm{mg} / \mathrm{L}$ & 57 & [58] \\
\hline Imidacloprid & Nannochloropsis sp. & Biodegradation & $9.59 \mu \mathrm{g} / \mathrm{L}$ & 50 & [71] \\
\hline Isoproturon & $\begin{array}{l}\text { Chlamydomonas } \\
\text { reinhardtii }\end{array}$ & $\begin{array}{l}\text { Bioaccumulation, } \\
\text { biodegradation }\end{array}$ & $50 \mu \mathrm{g} / \mathrm{L}$ & 15.1 & {$[65]$} \\
\hline Lindane & Nannochloris oculata & Bioaccumulation & $0.1 \mathrm{mg} / \mathrm{L}$ & 73 & [72] \\
\hline Malathion & Chlorella sorokiniana & Biodegradation & $25,100 \mathrm{ppm}$ & $(90,70)$ & [73] \\
\hline Mesotrione & Scenedesmus quadricauda & Biodegradation & $5 \mathrm{mg} / \mathrm{L}$ & 15.2 & [74] \\
\hline Metalaxyl & Chlorella vulgaris & Biodegradation & 4 ppm & 100 & [75] \\
\hline Prometryne & Chlamydomonas reinhartii & Biodegradation & $7.5 \mu \mathrm{g} / \mathrm{L}$ & 32 & [76] \\
\hline Trichlorfon & Chlamydomonas reinhartii & Biodegradation & $200 \mathrm{mg} / \mathrm{L}$ & 96.2 & [59] \\
\hline
\end{tabular}

\subsection{Bioaccumulation}

Bioaccumulation is a metabolism-dependent process known as active biosorption. It involves two mechanisms: the first is similar to biosorption, and the second step is the active transportation of ions into cells [77]. It is defined as the transfer process of pollutants into the interior of living cells. This process is driven by energy which requires the microalgae to transfer pesticides compounds across the cell membrane for accumulation and metabolization [68]. Studies also show that microalgae can undergo the metabolic mechanism of bioaccumulation $[72,78]$.

\subsection{Biodegradation}

Biodegradation of pesticides by microalgae into smaller molecules acts as a nutrient source to supplement microalgae growth [79]. The biodegradation of pesticides depends on the metabolic activity of various enzymes such as hydrolase, phosphatase, phosphotriesterase, oxygenase, esterase, transferase, and oxidoreductases $[80,81]$. There are three methods involved in the degradation of the pesticide involving enzyme metabolisms [82-84]. Firstly, via oxidation, reduction, and hydroxylation reactions of the activation of pesticides in the absence of functional groups by cytochrome P450. This is to gain more degradable, hydrophilic, soluble, and more intoxicant compounds. Secondly, the conjugation with glutathione, glucose, and malonate is formed by transferring the enzymes in the cytosol to pesticides that have functional groups. Thirdly, via glutathione transporters, the conjugates are transported into vacuoles [85]. The importance of biosorption, bioaccumulation, and biodegradation process in the microalgae removal of pesticides was postulated; the mechanism of action by microalgae remediation for diverse pesticides needs further investigation.

\section{Microalgae as Biological Remediating Agent for Pesticides: Bibliometric Trend Analysis}

\subsection{Bibliometric Data and Methodology}

Bibliometrics is the systematic review of articles, books, and other academic papers using quantitative tools in scientific data and collection libraries [86,87]. Methodologies such as keyword co-occurrences analysis, publications, and worldwide research trends in a decade were used to detect the development of research themes. Hence, the current biblio- 
metric study is required to revise and assess the available research on bioremediation of pesticides by microalgae, which involves synthesizing the core literature work, identifying critical points, and modeling potential research paths.

The first step in performing a bibliometric analysis is to select the ideal datasets that complements the scientific scope of a study area. Although there are several bibliographic databases, such as Scopus, Web of Science (WoS), PubMed, Google Scholar (GS) and Dimensions, most of them do not include relevant data that permit bibliometric analysis to be performed readily [88]. In addition, $84 \%$ of WoS titles are likewise indexed in Scopus, however only $54 \%$ of Scopus titles are indexed in WoS [89].

An Elsevier based abstract and citation database, Scopus is the only database that integrates a copious, carefully managed abstract and citation repository with augmented data and associated academic papers from a broad spectrum of fields. The database recognizes professionals, locates essential and credible work, and offers substantial algorithms and statistical analysis [90,91]. Meanwhile, PubMed is a journal search engine that allows users access to the MEDLINE database of biomedical and life science publications. Multiple bibliometric reviews have used Scopus or PubMed to assist bibliometric assessments [92-94] (Table 3).

Table 3. Features and accessibilities of both Scopus and PubMed scholarly databases for bibliometric studies.

\begin{tabular}{|c|c|c|}
\hline Element & Scopus $[86,95,96]$ & PubMed $[86,94,97]$ \\
\hline Coverage & $\sim 82$ million items & $\sim 32$ million items \\
\hline Discipline & Multidisciplinary & Medicine or biological sciences \\
\hline Bibliographic & 1.7 billion & Not available \\
\hline Provider & Elsevier & National Institute of Science (NIH) \\
\hline Accessibility & $\begin{array}{ll}\text { - } & \text { Accessible only to subscribed } \\
\text { institutions } \\
\text { - } & \text { Limited-free preview }\end{array}$ & Free \\
\hline Features & $\begin{array}{ll}\text { - } & \text { Author profiles } \\
\text { - } & \text { Bibliometric trend analysis } \\
\text { - } & \text { h-index calculator } \\
\text { - } & \text { Journal rankings } \\
\text { - } & \text { Easy to navigate }\end{array}$ & $\begin{array}{l}\text { - } \\
\text { Access to citations and } \\
\text { abstracts } \\
\text { Full text links to free PDFs or } \\
\text { publisher sites }\end{array}$ \\
\hline
\end{tabular}

Bibliometric search strategies were applied as shown in Figure 1. From 2010 to 2020, the subscription-based Scopus and free search engine PubMed databases were used to search, retrieve, and perform research pattern analysis on the utilization of microalgae as pesticide bioremediation agents. Specific query keywords "((pesticide OR pesticides) AND microalgae AND (bioremediation OR remediation))" related to the main idea were applied through "Title, Abstract, Keywords" in both databases. Between the publishing years of 1994-2020 (PubMed) and 1996-2020 (Scopus), all single categories of documents were included and sorted into the English language. In our primary screening, 46 and 43 papers, were discovered, respectively, from the Scopus and PubMed databases between 1994 and 2020. A limited number of documents was collected through the databases due to the specific of keywords used in the search engine. Following that, a spotlight on publications between 2010 and 2020 was explored to analyze the most recent research evolution on integrating microalgae as a bioremediation technique for pesticides. Scopus and PubMed detected 42 and 35 documents respectively corresponding to each database. The annual publishing output trends were organized through Excel Version 2017 (Microsoft, Redmond, DC, USA). All bibliometric investigations were conducted using Scopus, which provided 9.9\% more hits than PubMed. The eligibility of datasets was thoroughly checked prior to content visualization. 


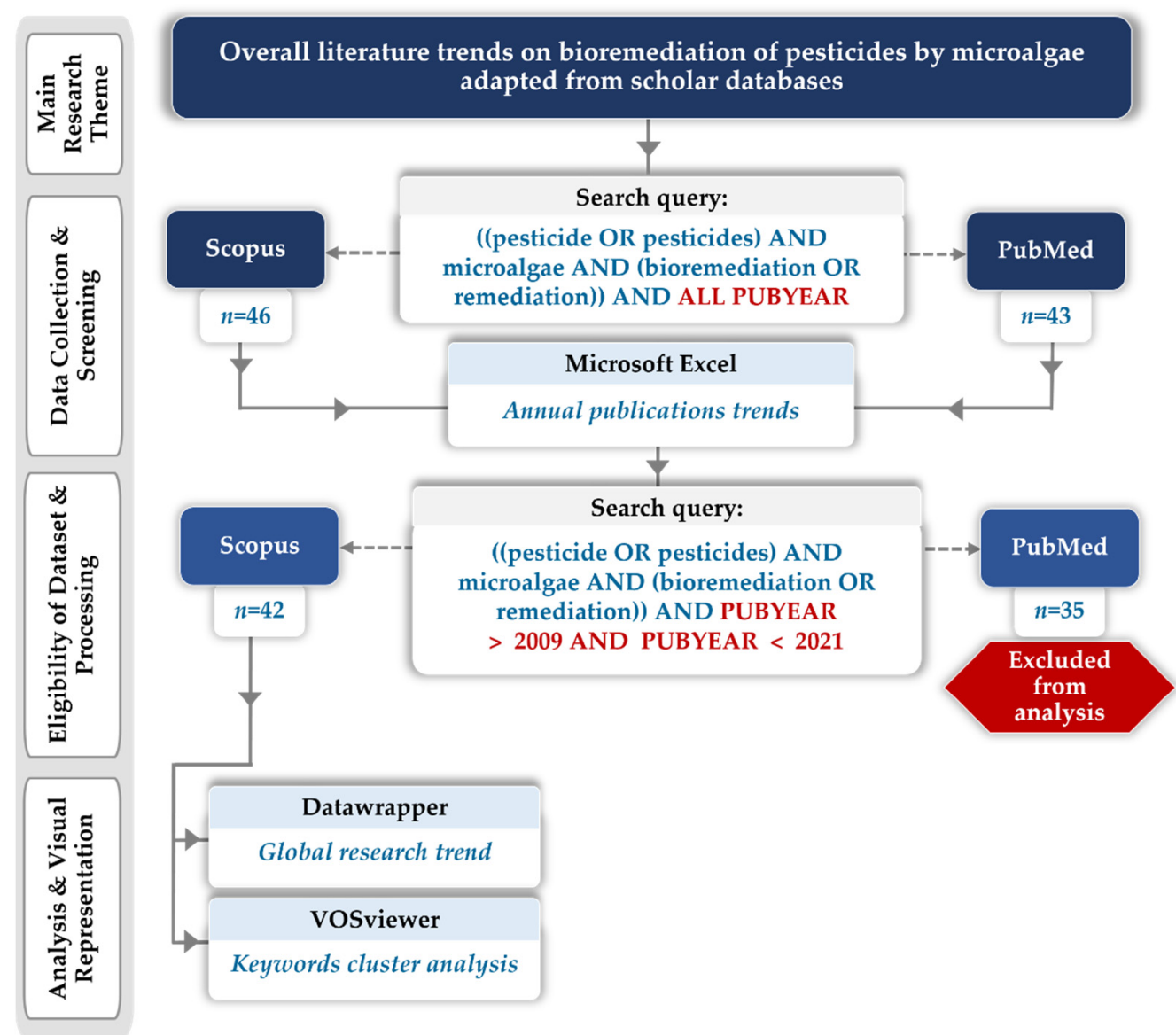

Figure 1. Bibliometric protocol for identifying and processing scholarly documents based on research topic.

The Visualization of Similarities Viewer or VOSviewer (version 1.6.15., Leiden University, Leiden, The Netherlands) and Datawrapper were used to visualize the processed Scopus datasets. VOSviewer is a program that allows users to create and visualize systematic mapping networks $[98,99]$. Collaborative filtering capabilities are included in VOSviewer, which may be used to create and visualize cluster networks of relevant terms retrieved from a collection of published studies [99]. Datawrapper (Datawrapper $\mathrm{GmbH}$ ) is an online charting tool that collects data from a specific data source and converts it into well-designed charts, maps, and tables that can be interpreted relatively quickly [100]. The outlook for the author's keyword co-occurrences and publication development by global nations was presented and discussed.

\subsection{Bibliometric Evolution Analysis}

Annually published documents on the bioremediation of pesticides by microalgae and their literature pattern were presented in Figure 2. A total of 42 and 35 documents were identified from the Scopus and PubMed databases respectively. There was a substantial gap in the publishing trend between 1994 and 2020 for both databases, indicating that the publication pattern had an inconsistent evolution. Scopus and PubMed revealed that no research or publications on pesticide bioremediation by microalgae were undertaken in 1997, 1999, 2000, 2003, 2005, or 2009. However, according to both databases, after a stagnant publication period from 1994 to 2009, an exponential trend was observed from 2010 forward. The development of research trends from 2017 to 2020 was noticeably constant for PubMed articles, whereas a significant growth in publication production was identified from Scopus database. Amidst the inconsistencies, the linear modelling resulted in a good $\mathrm{r}^{2}$ values of 0.9023 (Scopus) and 0.9921 (PubMed). The calculated trend was 1.6 
and 1.7 publications per year, respectively to PubMed and Scopus search outputs, which indicates the rise in publication rate. The following bibliometric analyses centered on the latest research shift on bioremediation of pesticides by microalgae between 2010 and 2020 from Scopus database ( $n=42$ documents) (Table 4) [10,101-105].

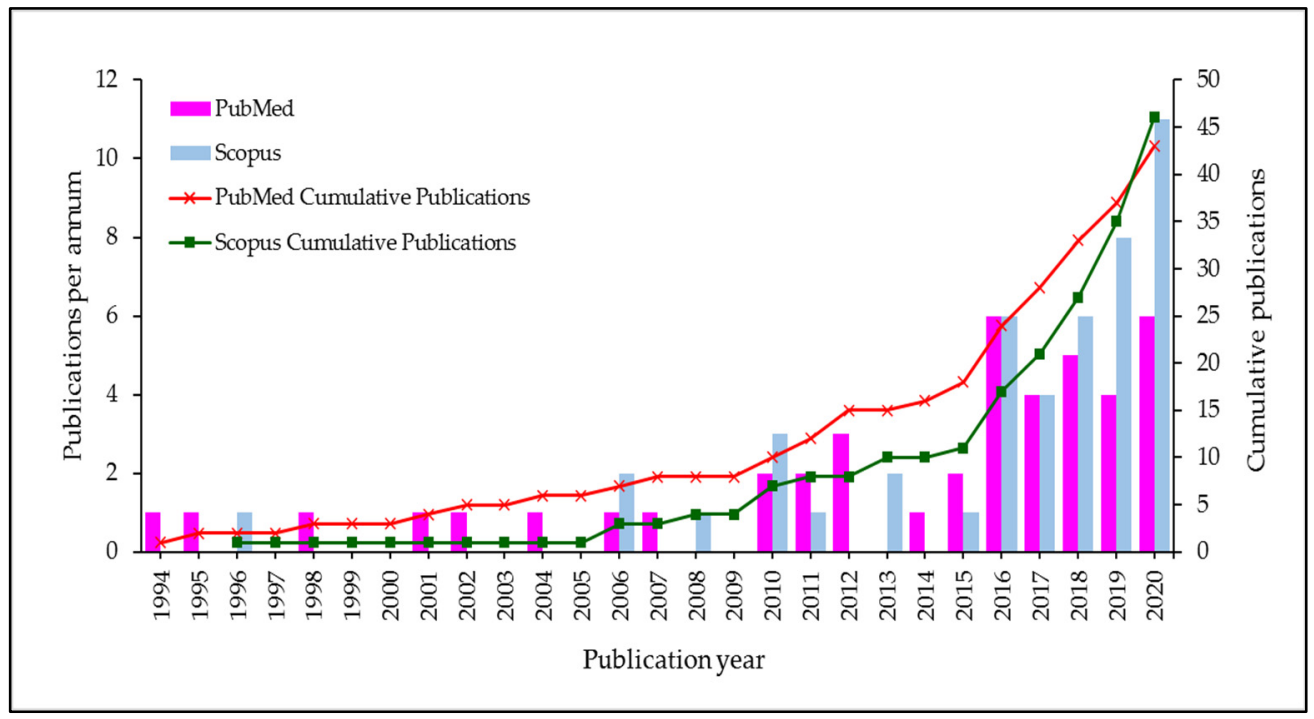

Figure 2. Annual research publication trends from 1994-2020 for both PubMed and Scopus database.

Table 4. List of documents retrieved from the Scopus database between 2010 and 2020.

\begin{tabular}{|c|c|c|c|c|c|}
\hline No. & Year & Document Type & Title & Author Keywords & Reference \\
\hline 1 & 2020 & Article & $\begin{array}{l}\text { Permeable reactive } \\
\text { surface-biobarriers. Testing and } \\
\text { evaluation of an ecotechnology for } \\
\text { the removal of agrotoxic } \\
\text { compounds carried by } \\
\text { agricultural runoffs }\end{array}$ & $\begin{array}{l}\text { Ecotechnology, nonpoint source } \\
\text { pollution; Micractinium sp.; } \\
\text { microbial community; sustainable } \\
\text { remediation }\end{array}$ & [106] \\
\hline 2 & 2020 & Article & $\begin{array}{l}\text { Microalgae-based bioremediation } \\
\text { of water contaminated by pesticides } \\
\text { in peri-urban agricultural areas }\end{array}$ & $\begin{array}{l}\text { Agriculture; contaminants of } \\
\text { emerging concern; ecotoxicity; } \\
\text { low-cost treatment; photobioreactor }\end{array}$ & [107] \\
\hline 3 & 2020 & Article & $\begin{array}{l}\text { Potential for bifenthrin removal } \\
\text { using microalgae from a } \\
\text { natural source }\end{array}$ & $\begin{array}{l}\text { Bifenthrin; bioremediation; } \\
\text { microalgae; pesticide; } \\
\text { phycoremediation; residual waters }\end{array}$ & [69] \\
\hline 4 & 2020 & Article & $\begin{array}{l}\text { Reactive Oxygen Species } \\
\text { (ROS)-mediated degradation of } \\
\text { organophosphate pesticides by the } \\
\text { green microalgae Coccomyxa } \\
\text { subellipsoidea }\end{array}$ & $\begin{array}{l}\text { Algae; bioremediation; } \\
\text { organophosphate pesticide; reactive } \\
\text { oxygen species; water quality }\end{array}$ & [108] \\
\hline 5 & 2020 & Review & $\begin{array}{l}\text { Applications of microalgal and } \\
\text { cyanobacterial biomass on a way to } \\
\text { safe, cleaner, and a sustainable } \\
\text { environment }\end{array}$ & $\begin{array}{l}\text { Biofuel; cyanobacteria; microalgae; } \\
\text { secondary metabolites; } \\
\text { value-added products; wastewater }\end{array}$ & [109] \\
\hline 6 & 2020 & Article & $\begin{array}{l}\text { Bioremediation of water containing } \\
\text { pesticides by microalgae: } \\
\text { mechanisms, methods, and } \\
\text { prospects for future research }\end{array}$ & $\begin{array}{l}\text { Biodiesel; green remediation; } \\
\text { microalgae; pesticide; water } \\
\text { pollution }\end{array}$ & [11] \\
\hline
\end{tabular}


Table 4. Cont.

\begin{tabular}{|c|c|c|c|c|c|}
\hline No. & Year & Document Type & Title & Author Keywords & Reference \\
\hline 7 & 2020 & Article & $\begin{array}{l}\text { Kinetic study of nutrients removal } \\
\text { from municipal wastewater by } \\
\text { Chlorella vulgaris in photobioreactor } \\
\text { supplied with } \mathrm{CO}_{2} \text {-enriched air }\end{array}$ & $\begin{array}{l}\text { Chlorella vulgaris; kinetic study; } \\
\text { municipal wastewater; nutrient } \\
\text { bioremediation; photobioreactor }\end{array}$ & [110] \\
\hline 8 & 2020 & Article & $\begin{array}{l}\text { Toxicity, Biodegradation, and } \\
\text { Metabolic Fate of } \\
\text { Organophosphorus Pesticide } \\
\text { Trichlorfon on the Freshwater } \\
\text { Algae Chlamydomonas reinhardtii }\end{array}$ & $\begin{array}{l}\text { biodegradation; metabolic fate; } \\
\text { microalgae; toxicity; trichlorfon }\end{array}$ & [111] \\
\hline 9 & 2020 & Review & $\begin{array}{l}\text { Macro and Micro Algae in Pollution } \\
\text { Control and Biofuel } \\
\text { Production-A Review }\end{array}$ & $\begin{array}{l}\text { Algae; biofuel; biosorption; } \mathrm{CO}_{2} \\
\text { fixation; wastewater }\end{array}$ & [112] \\
\hline 10 & 2020 & Article & $\begin{array}{l}\text { Developments in enzyme and } \\
\text { microalgae based biotechniques to } \\
\text { remediate micropollutants from } \\
\text { aqueous systems-a review }\end{array}$ & $\begin{array}{l}\text { Bioremediation; laccase; microalgae; } \\
\text { peroxidase; wastewater treatment }\end{array}$ & [113] \\
\hline 11 & 2020 & Article & $\begin{array}{l}\text { The significance of tropical } \\
\text { microalgae Chlorella sorokiniana as a } \\
\text { remediate of polluted water caused } \\
\text { by chlorpyrifos }\end{array}$ & $\begin{array}{l}\text { Bioremediation; Chlorella } \\
\text { sorokiniana; chlorpyrifos; contact } \\
\text { time; pesticide }\end{array}$ & [114] \\
\hline 12 & 2019 & Review & $\begin{array}{l}\text { Biological contamination and its } \\
\text { chemical control in microalgal mass } \\
\text { cultures }\end{array}$ & $\begin{array}{l}\text { Algal parasites; contamination; } \\
\text { control; mass cultures; microalgae }\end{array}$ & [115] \\
\hline 13 & 2019 & Review & $\begin{array}{l}\text { Microalgal bioremediation of } \\
\text { emerging } \\
\text { contaminants-Opportunities and } \\
\text { challenges }\end{array}$ & $\begin{array}{l}\text { Aquatic pollution; bioadsorption; } \\
\text { Biodegradation; emerging } \\
\text { contaminants; microalgal treatment } \\
\text { systems }\end{array}$ & [9] \\
\hline 14 & 2019 & Article & $\begin{array}{l}\text { Sensitivity of selected tropical } \\
\text { microalgae isolated from a } \\
\text { farmland and a eutrophic lake to } \\
\text { atrazine and endosulfan }\end{array}$ & $\begin{array}{l}\text { Atrazine; chlorella; endosulfan; } \\
\text { microalgae; oxidative stress; } \\
\text { Scenedesmus }\end{array}$ & [116] \\
\hline 15 & 2019 & Article & $\begin{array}{l}\text { Evaluation of amicarbazone toxicity } \\
\text { removal through degradation } \\
\text { processes based on hydroxyl and } \\
\text { sulfate radicals }\end{array}$ & $\begin{array}{l}\text { amicarbazone degradation } \\
\text { products; pesticide; sulfate and } \\
\text { hydroxyl radicals-mediated } \\
\text { degradation; toxicity assays }\end{array}$ & [117] \\
\hline 16 & 2019 & Article & $\begin{array}{l}\text { Chemical mixtures and } \\
\text { fluorescence in situ hybridization } \\
\text { analysis of natural microbial } \\
\text { community in the Tiber river }\end{array}$ & $\begin{array}{l}\text { Anthropogenic pollution and } \\
\text { stressors; bioindicators; freshwater; } \\
\text { microbial populations; water } \\
\text { quality }\end{array}$ & [118] \\
\hline 17 & 2019 & Article & $\begin{array}{l}\text { The light-dependent lethal effects of } \\
\text { 1,2-benzisothiazol- } 3(2 \mathrm{H}) \text {-one and its } \\
\text { biodegradation by freshwater } \\
\text { microalgae }\end{array}$ & $\begin{array}{l}\text { 1,2-Benzisothiazol-3 }(2 \mathrm{H}) \text {-one; } \\
\text { biodegradation; environmental risk } \\
\text { estimation; light-dependent lethal } \\
\text { effects; microalgae }\end{array}$ & [119] \\
\hline 18 & 2019 & Review & $\begin{array}{l}\text { Acute hazard of biocides for the } \\
\text { aquatic environmental } \\
\text { compartment from a life-cycle } \\
\text { perspective }\end{array}$ & $\begin{array}{l}\text { Aquatic compartment; biocide; } \\
\text { metabolite; toxicity category }\end{array}$ & [120] \\
\hline 19 & 2019 & Article & $\begin{array}{l}\text { Bioremediation of a pesticide and } \\
\text { selected heavy metals in } \\
\text { wastewater from various sources } \\
\text { using a consortium of microalgae } \\
\text { and cyanobacteria }\end{array}$ & $\begin{array}{l}\text { Bioremediation; heavy metals; } \\
\text { microalgae; microorganisms; } \\
\text { pesticides; wastewater }\end{array}$ & [105] \\
\hline
\end{tabular}


Table 4. Cont.

\begin{tabular}{|c|c|c|c|c|c|}
\hline No. & Year & Document Type & Title & Author Keywords & Reference \\
\hline 20 & 2018 & Book Chapter & $\begin{array}{l}\text { Phytoremediation for the } \\
\text { elimination of metals, pesticides, } \\
\text { PAHs, and other pollutants from } \\
\text { wastewater and soil }\end{array}$ & - & [121] \\
\hline 21 & 2018 & Article & $\begin{array}{l}\text { Effects of fungal-assisted algal } \\
\text { harvesting through biopellet } \\
\text { formation on pesticides in water }\end{array}$ & $\begin{array}{l}\text { Aspergillus niger; bioremediation; } \\
\text { chlorella vulgaris; emerging } \\
\text { pollutants; water quality }\end{array}$ & [122] \\
\hline 22 & 2018 & Article & $\begin{array}{l}\text { Influence of bacteria on the } \\
\text { response of microalgae to } \\
\text { contaminant mixtures }\end{array}$ & $\begin{array}{l}\text { Metallic and pesticide } \\
\text { contaminants; Microbial } \\
\text { interactions; sediments }\end{array}$ & [123] \\
\hline 23 & 2018 & Book Chapter & $\begin{array}{l}\text { Phycotechnological approaches } \\
\text { toward wastewater management }\end{array}$ & $\begin{array}{l}\text { Microalgae; phycoremediation; } \\
\text { pollutant; wastewater }\end{array}$ & [124] \\
\hline 24 & 2018 & Book Chapter & Bioremediation by microalgae & $\begin{array}{l}\text { Biosorption; contamination; } \\
\text { environment; industrialization; } \\
\text { microalgae }\end{array}$ & [125] \\
\hline 25 & 2018 & Book Chapter & $\begin{array}{l}\text { Bioremediation of pesticides } \\
\text { residues: A psychological approach }\end{array}$ & $\begin{array}{l}\text { Bioremediation; cyanobacteria; } \\
\text { pesticides residue }\end{array}$ & [126] \\
\hline 26 & 2017 & Article & $\begin{array}{l}\text { Toxicity assessment of pesticide } \\
\text { triclosan by aquatic organisms and } \\
\text { degradation studies }\end{array}$ & $\begin{array}{l}\text { 2,4-Dichlorophenol; } \\
\text { biodegradation; cyanobacteria; } \\
\text { microalgae; toxicity; triclosan }\end{array}$ & [127] \\
\hline 27 & 2017 & Article & $\begin{array}{l}\text { Phytoremediation of } \\
\text { organochlorine and pyrethroid } \\
\text { pesticides by aquatic macrophytes } \\
\text { and algae in freshwater systems }\end{array}$ & $\begin{array}{l}\text { organochlorine; phytoremediation; } \\
\text { pyrethroids }\end{array}$ & [128] \\
\hline 28 & 2017 & Review & $\begin{array}{l}\text { Interaction of chiral herbicides with } \\
\text { soil microorganisms, algae, and } \\
\text { vascular plants }\end{array}$ & $\begin{array}{l}\text { Biodegradation; chiral herbicide; } \\
\text { enantiomer; enantioselective } \\
\text { toxicology; herbicide toxicity; plant }\end{array}$ & [129] \\
\hline 29 & 2017 & Book Chapter & $\begin{array}{l}\text { Technological approach of } \\
\text { bioremediation using microbial } \\
\text { tools: bacteria, fungi, and algae }\end{array}$ & - & [130] \\
\hline 30 & 2016 & Review & $\begin{array}{l}\text { Growth regime and environmental } \\
\text { remediation of microalgae }\end{array}$ & $\begin{array}{l}\text { Bioremediation; microalgae; } \\
\text { nutrient removal; wastewater }\end{array}$ & [10] \\
\hline 31 & 2016 & Article & $\begin{array}{l}\text { Landfill leachate treatment using } \\
\text { bacto-algal coculture: an integrated } \\
\text { approach using chemical analyses } \\
\text { and toxicological assessment }\end{array}$ & $\begin{array}{l}\text { Coculture; detoxification; landfill } \\
\text { leachate; lysimeter; treatment }\end{array}$ & [131] \\
\hline 32 & 2016 & Article & $\begin{array}{l}\text { Batch vs. continuous-feeding } \\
\text { operational mode for the removal } \\
\text { of pesticides from agricultural } \\
\text { run-off by microalgae systems: a } \\
\text { laboratory scale study }\end{array}$ & $\begin{array}{l}\text { Agricultural run-off; } \\
\text { biodegradation; microalgae; } \\
\text { pesticides; removal }\end{array}$ & [132] \\
\hline 33 & 2016 & Article & $\begin{array}{l}\text { Effect of microalgal treatments on } \\
\text { pesticides in water }\end{array}$ & $\begin{array}{l}\text { Bioremediation; biosorption; } \\
\text { Chlorella vulgaris; organic pollutants; } \\
\text { water treatment }\end{array}$ & [133] \\
\hline 34 & 2016 & Article & $\begin{array}{l}\text { Effect of the pesticide lindane on } \\
\text { the biomass of the microalgae } \\
\text { Nannochloris oculata }\end{array}$ & $\begin{array}{l}\text { chronic toxicity; microalgae; } \\
\text { organochloride pesticide; } \\
\text { phycoremediation; removal }\end{array}$ & [81] \\
\hline 35 & 2016 & Review & Substratum-associated microbiota & $\begin{array}{l}\text { Algae; bacteria; biofilm; } \\
\text { cyanobacteria; diatoms; microbes; } \\
\text { periphyton }\end{array}$ & [134] \\
\hline
\end{tabular}


Table 4. Cont.

\begin{tabular}{|c|c|c|c|c|c|}
\hline No. & Year & Document Type & Title & Author Keywords & Reference \\
\hline 36 & 2015 & Article & $\begin{array}{l}\text { Capability of microalgae-based } \\
\text { wastewater treatment systems to } \\
\text { remove emerging organic } \\
\text { contaminants: A pilot-scale study }\end{array}$ & $\begin{array}{l}\text { Biodegradation; emerging organic } \\
\text { contaminants; high-rate algal pond; } \\
\text { microalgae; photodegradation; } \\
\text { volatilization }\end{array}$ & [135] \\
\hline 37 & 2013 & Book Chapter & $\begin{array}{l}\text { Toxicity and removal of organic } \\
\text { pollutants by microalgae: A review }\end{array}$ & - & [136] \\
\hline 38 & 2013 & Review & $\begin{array}{l}\text { Mixotrophic cyanobacteria and } \\
\text { microalgae as distinctive biological } \\
\text { agents for organic pollutant } \\
\text { degradation }\end{array}$ & $\begin{array}{l}\text { Biodegradation; biological agents; } \\
\text { cyanobacteria; microalgae; } \\
\text { mixotrophy; organic pollutants }\end{array}$ & [137] \\
\hline 39 & 2011 & Article & $\begin{array}{l}\text { Bioaccumulation and degradation } \\
\text { of pesticide fluroxypyr are } \\
\text { associated with toxic tolerance in } \\
\text { green alga Chlamydomonas } \\
\text { reinhardtii }\end{array}$ & $\begin{array}{l}\text { Bioaccumulation; biodegradation; } \\
\text { Chlamydomonas reinhardtii; } \\
\text { fluroxypyr; oxidation }\end{array}$ & [138] \\
\hline 40 & 2010 & Conference Paper & $\begin{array}{l}\text { Microalgal remediation of } \\
\text { sewage effluent }\end{array}$ & $\begin{array}{l}\text { Heavy metals; microalgae; nitrogen; } \\
\text { phosphorous; sewage; wastewater }\end{array}$ & [139] \\
\hline 41 & 2010 & Article & $\begin{array}{l}\text { Cleanup of atrazine-contaminated } \\
\text { soils: Ecotoxicological study on the } \\
\text { efficacy of a bioremediation tool } \\
\text { with Pseudomonas sp. ADP }\end{array}$ & $\begin{array}{l}\text { Atrazine; bioremediation; } \\
\text { ecotoxicology; pesticides; soil } \\
\text { contamination }\end{array}$ & [140] \\
\hline 42 & 2010 & Article & $\begin{array}{l}\text { Fungicides and herbicide removal } \\
\text { in Scenedesmus cell suspensions }\end{array}$ & $\begin{array}{l}\text { Bioremediation; chlorophyll } \\
\text { fluorescence; Scenedesmus; toxicity; } \\
\text { uptake }\end{array}$ & [73] \\
\hline
\end{tabular}

\subsection{Global Publications Contribution}

The worldwide map in Figure 3 displayed the general distribution of publications associated with 28 countries between 2010 and 2020. India provided the most scientific contributions on the research topic $(23.8 \%)$, followed by China $(16.7 \%)$. The United States, Sweden, and Spain each provided 9.5\% of the publications; the United Kingdom, Brazil, France, and Egypt contributed 7.1\% of the publications; and Australia, Hong Kong, Malaysia, Mexico, and Portugal contributed 4.8\%. Between 2010 and 2020, the remaining $50 \%$ of the nations generated at least one article (2.4\%).

\subsection{Author's Keywords Cluster Analysis and Literature Review}

The relatedness of items is defined by the number of documents that appeared together in a co-occurrence analysis. When it comes to analyzing and controlling research interests and development patterns, keywords might drive the limitations of a study $[110,119]$. Figure 4 was constructed on the co-occurrences of the author's keywords, generating 17 clusters with 348 links and the total link strength (TLS) of 377 assigned in different colors. Nodes of identical colors were designated to a cluster, and the outcomes accurately portrayed the research's concepts and trends in a discipline area. In the network visualization, the minimum number of occurrences of a keyword was set to one, and 108 keywords met the threshold. The nodes reflected the author's keywords that related to bioremediation of pesticides by microalgae. The size of the nodes, which denoted keywords, was relative to the number of occurrences in which the author's keyword exists. The strength of the keywords co-occurrences can be seen in the lines that connected these nodes. The number of links connecting them indicated the intensity of node-to-node interactions. The thickness of the connecting lines denoted by the degrees of keyword co-occurrences linked to the 
nodes $[116,133]$. The similarity $\left(S_{a b}\right)$, between two items $a$ and $b$ is estimated using the correlation strength as follows:

$$
S_{a b}=\frac{C_{a b}}{W_{a} W_{b}}
$$

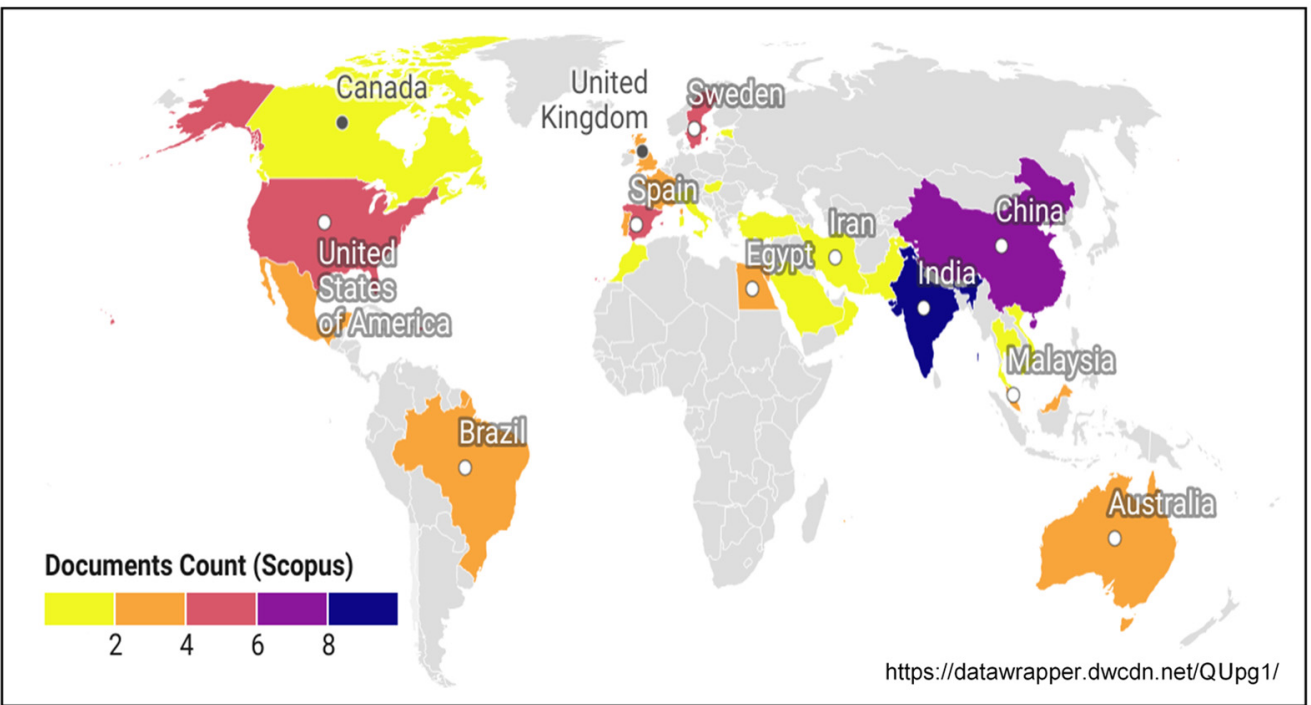

Figure 3. Globally distributed publications on research topic, bioremediation of pesticides by microalgae from 2010-2020.

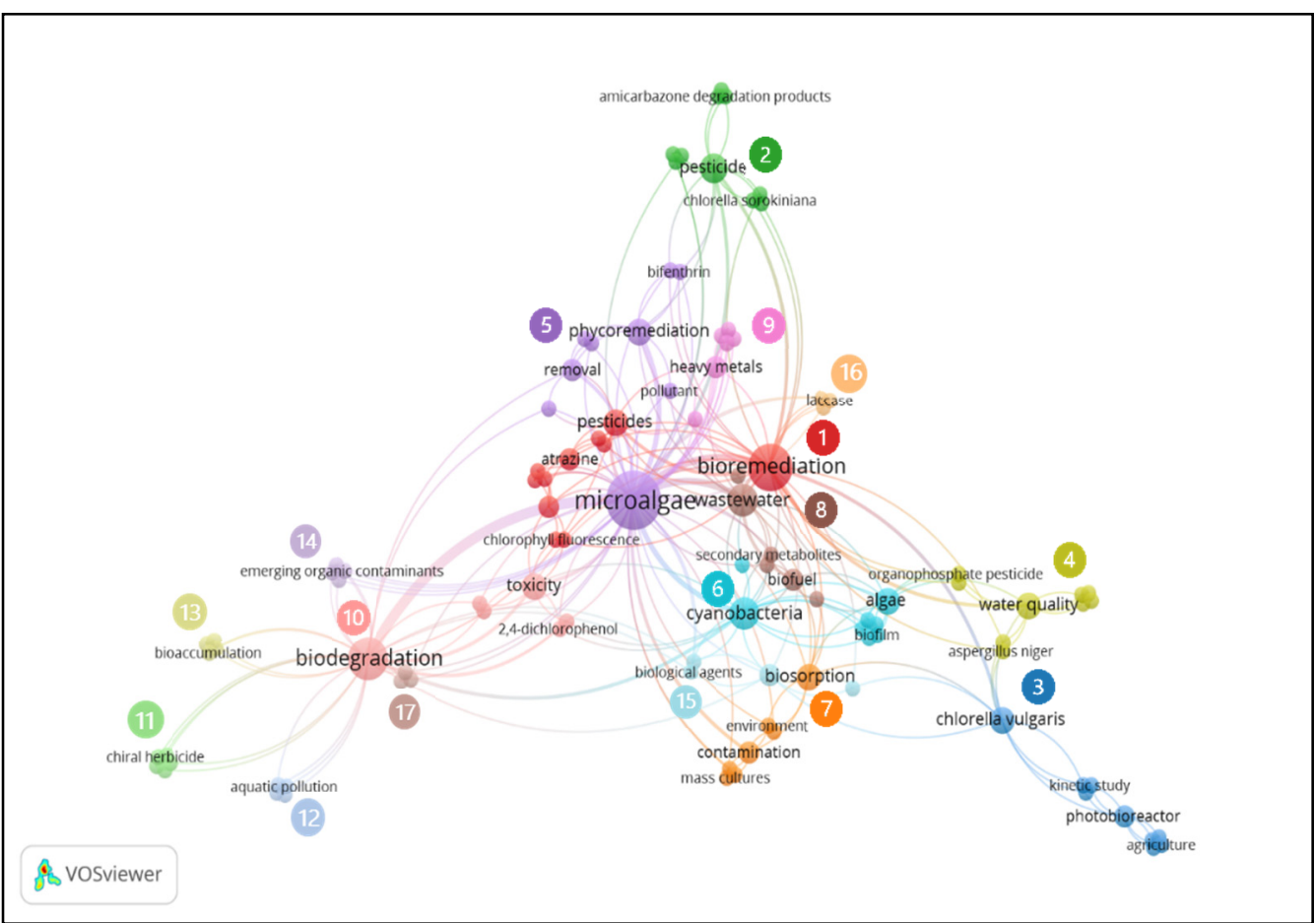

Figure 4. Network cluster visualization based on all authors' keyword co-occurrences generated based on Scopus dataset produced 17 clusters ( $n=108$ keywords).

$C_{a b}$ is the co-occurrences quantity of items $a$ and $b$, whereas $W_{a}$ and $W_{b}$ are the overall frequency of occurrences of items $a$ and $b$ or the sum of both co-occurrences [89].

In the dynamic field of bioremediation or biodegradation, publication keywords offer practical evidence of authors' research themes and objectives, as visualized in Figure 4. The cluster network on this topic built based on the top 10 author's keywords, were 
"microalgae" (TLS 78) with strongest research network, followed by "bioremediation" (TLS 43), “biodegradation" (TLS 40), "cyanobacteria" (TLS 23), "wastewater" (TLS 20), "pesticide" (TLS 16), and the rest are listed in Table 5.

Table 5. List of author's keywords as central of top 10 clusters in co-occurrence's analysis.

\begin{tabular}{ccccc}
\hline Cluster & Author Keyword & Links & TLS & Occurrences \\
\hline 1 & Bioremediation & 35 & 43 & 11 \\
2 & Pesticide & 14 & 16 & 4 \\
3 & Chlorella vulgaris & 11 & 12 & 3 \\
4 & Water quality & 11 & 12 & 3 \\
5 & Microalgae & 57 & 78 & 18 \\
6 & Cyanobacteria & 20 & 23 & 5 \\
7 & Biosorption & 12 & 12 & 3 \\
8 & Wastewater & 15 & 20 & 5 \\
9 & Heavy metals & 9 & 10 & 2 \\
10 & Biodegradation & 33 & 40 & 9 \\
\hline
\end{tabular}

The cluster network showed a profound number of diverse clusters (top 5 clusters), indicating the heterogeneity of topics amongst the main researchers. Cluster 1 refers to "bioremediation" of "pesticides" by common green microalgae from the genus "Chlorella" and "Scenedesmus". Microalgae are fundamental in the food web as primary producers and have a great extent of ecological tolerance. As a result, microalgae with their great value as commercialized biomass, were effectively employed in mitigating pollutants (oil, heavy metals, pharmaceutical chemicals, dyes, wastewater treatment etc.) [141]. Algae can digest contaminants enzymatically and utilize the substrates as a source of nutrients. One of their bioremediation techniques is the bio-uptake of pesticides compounds into the cells' compartments through three pathways of diffusions (passive diffusion, active transport, and passive-facilitated diffusion) across the cell membrane [117]. Some of their notable applications as a bioremediating agents are Chlorella vulgaris (amicarbazone) [142]; consortium of microalgae and cyanobacteria Chlorella vulgaris, Scenedesmus quadricuda, and Spirulina platensis (organophosphate malathion) [100]; Scenedesmus arcuatus (atrazine and endosulfan) [101] and Chlorella vulgaris (1,2-benzisothiazol-3(2H)-one (BIT)) [119].

Cluster 2 is centralized by the keywords "pesticide", "amicarbazone degradation products", "biodiesel", and "Chlorella sorokiniana". The most effective removal of organophosphate chlorpyrifos by microalgae Chlorella sorokiniana was proposed by Habibah et al. [142] at various concentrations of $99.85 \%$ (300 ppm), 99.18\% (100 ppm), and $97.86 \%(500 \mathrm{ppm})$ in polluted water bodies. Algal biomass generated after wastewater treatment is recycled and potentially used for biochar generation and biodiesel production [9].

Several authors' keywords identified in Cluster 3 were "Chlorella vulgaris", "kinetic study", "photobioreactor", and "agriculture". In a study by García-Galán et al. [107,114], the removal efficiency of several pesticides from agricultural run-off by mix microalgae culture in a microalgae based-photobioreactor found the promising treatment to mitigate diverse arrays of pesticides. The application of microalgae in the mentioned system proved to be remarkably release treated effluent and produce microalgae biomass, which may subsequently transform into renewable energy [122].

Apart from that, in Cluster 4, the keywords "Aspergillus niger", "organophosphate pesticide", "bioindicators" were interconnected with the largest node, "water quality". The application of fungus (Aspergillus niger) for harvesting microalgae (Chlorella vulgaris) via biopellet formation has a great potential for sustainable development. Reduced level of pesticides were observed after the harvesting procedure [108]. In another study, a unicellular green microalga, Coccomyxa subellipsoidea, demonstrated the ability to metabolize organophosphates from agricultural run-off with minimal toxicity to the cell by producing ROS [143].

From Cluster 5, the term "microalgae" has the greatest number of connecting (78 links) co-occurring keywords with a TLS of 78 in the network cluster. The term "phycoremedia- 
tion" relates to the "microalgae" distinct potential to metabolize and sequestrate carbon sources in comparison with that of other microorganisms [111,144]. Fluroxypyr is an herbicide commonly used to manage weeds and insects, but its extensive usage has led to substantial damage to the soil and surrounding waters. The rapid bioaccumulation, degradation (57\% cellular breakdown), and biological adaptation of fluroxypyr in Chlamydomonas reinhardtii were stimulated through ROS formation and the actions of antioxidative enzymes $[108,145]$. The keywords cluster revealed 5 out of a total of 17 clusters focusing on topics involving bioremediation of pesticides and their byproducts, wastewater treatment, bioindicators, and phycoremediation meanwhile, the remaining clusters, contributed to the overall research trend's development. Remediation of pollutants by microalgae or macroalgae in a water system is described as phycoremediation. Photosynthesis allows algae to fix carbon dioxide and eliminate excess nutrients at a low cost. It cleans wastewater of harmful microbes and toxins [85]. Moreover, microalgal biomass produced through the remediation process is more beneficial than conventional biomass generation. Recycled microalgae biomass produced in large quantities could be used for a wide range of applications (for example, biodiesel production, feed, cosmetics, pharmaceuticals, and electricity) [11]. Frequent pesticide application decreases crop production because of their long-lasting and accumulative nature, which could potentially create substantial environmental effects.

\section{Conclusions}

The environmentally destructive application of pesticides in agriculture severely influences the ecosystem, inflicting damage on biodiversity and aquatic systems. This work demonstrated the research progress in recent times through bibliometric analytical review. In this case, bibliometric analysis can aid researchers in comprehending the global trend and serving as a model for future study. The evolution of the present research trend on bioremediation of pesticides by microalgae from 2010 to 2016 appeared to fluctuate. However, between 2017 and 2020, the trend was noticeably consistent for PubMed articles, and the Scopus dataset demonstrated a significant increase in publication productivity. Economically developed countries such as India and China progressively contributed to the scientific communities in investigating sustainable remediation strategies for pesticiderelated pollutions. The study's topic of investigation was guided by the author's keyword clustering networks, which included "microalgae," "bioremediation," "biodegradation," "cyanobacteria," "wastewater", and "pesticide." Microalgae are a naturally occurring biological agent that was described as one of the most suitable techniques for pollution control and efficient at eliminating pesticide contaminants from agricultural run-off and polluted water effluents. Indeed, a proactive approach such as bioremediation could help improve the quality of the environment, and it must be developed by acknowledging the ability of microalgae and their metabolic functions.

Author Contributions: Conceptualization, S.A.A. and N.A.S.; methodology, S.A.A., N.A.S. and G.V.; software, G.V.; writing—original draft preparation, G.V., Z.S.L., S.B.M.R., S.H.T. and N.A.P.; writing-review and editing, S.A.A., N.A.S., F.M., C.-Y.W. and J.L.; supervision, S.A.A., N.A.S., F.M., C.-Y.W. and J.L.; project administration, S.A.A. and N.A.S.; All authors have read and agreed to the published version of the manuscript.

Funding: The APC was funded by Universiti Putra Malaysia.

Institutional Review Board Statement: Not applicable.

Informed Consent Statement: Not applicable.

Data Availability Statement: Not applicable.

Acknowledgments: The authors also would like to thank Universiti Putra Malaysia, International Medical University, and Universiti Sains Malaysia.

Conflicts of Interest: The authors declare no conflict of interest. 


\section{References}

1. McLellan, J.; Gupta, S.K.; Kumar, M. Feasibility of Using Bacterial-Microalgal Consortium for the Bioremediation of Organic Pesticides: Application Constraints and Future Prospects. In Application of Microalgae in Wastewater Treatment Volume 1: Domestic and Industrial Wastewater Treatment; Gupta, S.K., Bux, F., Eds.; Springer: Cham, Switzerland, 2019; pp. 341-362. [CrossRef]

2. Abdel-Raouf, N.; Al-Homaidan, A.A.; Ibraheem, I.B.M. Microalgae and Wastewater Treatment. Saudi J. Biol. Sci. 2012, 19, $257-275$. [CrossRef]

3. Avila, R.; Peris, A.; Eljarrat, E.; Vicent, T.; Blánquez, P. Biodegradation of Hydrophobic Pesticides by Microalgae: Transformation Products and Impact on Algae Biochemical Methane Potential. Sci. Total Environ. 2021, 754, 142114. [CrossRef]

4. Raffa, C.M.; Chiampo, F. Bioremediation of Agricultural Soils Polluted with Pesticides: A Review. Bioengineering $2021,8,92$. [CrossRef]

5. Sarath Chandran, C.; Thomas, S.; Unni, M.R. Pesticides: Classification, Detection, and Degradation. In Organic Farming; Sarath Chandran, C., Thomas, S., Unni, M.R., Eds.; Springer: Cham, Switzerland, 2019; pp. 71-87. [CrossRef]

6. Conway, G.R.; Barbie, E.B. After the Green Revolution: Sustainable and Equitable Agricultural Development. Futures 1988, 20, 651-670. [CrossRef]

7. Singh, R.; Singh, P.; Sharma, R. Microorganism as a Tool of Bioremediation Technology for Cleaning Environment: A Review. Proc. Int. Acad. Ecol. Environ. Sci. 2014, 4, 1-6.

8. Prabha, R.; Singh, D.P.; Verma, M.K. Microbial Interactions and Perspectives for Bioremediation of Pesticides in the Soils. Plant-Microbe Interact. Agro-Ecol. Perspect 2017, 2, 649-671. [CrossRef]

9. Sutherland, D.L.; Ralph, P.J. Microalgal Bioremediation of Emerging Contaminants-Opportunities and Challenges. Water Res. 2019, 164, 114921. [CrossRef]

10. Hammed, A.M.; Prajapati, S.K.; Simsek, S.; Simsek, H. Growth Regime and Environmental Remediation of Microalgae. Algae 2016, 31, 189-204. [CrossRef]

11. Nie, J.; Sun, Y.; Zhou, Y.; Kumar, M.; Usman, M.; Li, J.; Shao, J.; Wang, L.; Tsang, D.C.W. Bioremediation of Water Containing Pesticides By Microalgae: Mechanisms, Methods, and Prospects For Future Research. Sci. Total Environ. 2020, 707, 136080. [CrossRef]

12. Liu, X.; Zhang, X.; Herbert, S.J. Feeding China's Growing Needs for Grain. Nature 2010, 465, 420. [CrossRef]

13. Food and Agriculture Organization of the United Nations (FAO). The Impact of Disasters and Crises on Agriculture and Food Security; FAO: Rome, Italy, 2021. [CrossRef]

14. Roser, M.; Pesticides-Our World in Data. Food and Agriculture Organization of the United Nations (FAO). Available online: https:/ / ourworldindata.org/pesticides (accessed on 24 August 2021).

15. Maksymiv, I. Pesticides: Benefits and Hazards. J. Vasyl Stefanyk Precarpathian Natl. Univ. 2015, 2, 70-76. [CrossRef]

16. Au, A.M. Pesticides and Herbicides I Types, Uses, and Determination of Herbicides. In Encyclopedia of Food Sciences and Nutrition; Academic Press: Cambridge, MA, USA, 2003; pp. 4483-4487. [CrossRef]

17. Varanasi, A.; Prasad, P.V.; Jugulam, M. Impact of Climate Change Factors on Weeds and Herbicide Efficacy. Adv. Agron. 2016, 135, 107-146. [CrossRef]

18. Song, Y. Insight into the Mode of Action of 2,4-Dichlorophenoxyacetic Acid (2,4-D) as an Herbicide. J. Integr. Plant Biol. 2014, 56, 106-113. [CrossRef] [PubMed]

19. Jyothi, K.B. Study of Herbicidal Effect of 2,4-D on Growth and Cellular Metabolites in Cyanobacterium Synechococcus aeruginosus from Rice Fields. J. Algal Biomass Util. 2016, 7, 1-3.

20. Pazmiño, D.M.; Rodríguez-Serrano, M.; Romero-Puertas, M.C.; Archilla-Ruiz, A.; del Río, L.A.; Sandalio, L.M. Differential Response of Young and Adult Leaves to Herbicide 2,4-Dichlorophenoxyacetic Acid in Pea Plants: Role of Reactive Oxygen Species. Plant. Cell Environ. 2011, 34, 1874-1889. [CrossRef] [PubMed]

21. Ma, Q.; Ding, Y.; Chang, J.; Sun, X.; Zhang, L.; Wei, Q.; Cheng, Y.; Chen, L.; Xu, J.; Deng, X. Comprehensive Insights on How 2,4-Dichlorophenoxyacetic Acid Retards Senescence in Post-Harvest Citrus Fruits Using Transcriptomic and Proteomic Approaches. J. Exp. Bot. 2014, 65, 61-74. [CrossRef]

22. Lal, D.; Tripathi, V.K.; Kumar, S.; Nayyer, A. Effect of Pre-Harvest Application of Gibberellic Acid, NAA, and Calcium Nitrate on Fruit Drop, Maturity and Storage Quality of Kinnow Mandarin. Res. Environ. Life Sci. 2015, 8, 561-564.

23. Koger, C.H.; Burke, I.C.; Miller, D.K.; Kendig, J.A.; Reddy, K.N.; Wilcut, J.W. MSMA Antagonizes Glyphosate and Glufosinate Efficacy on Broadleaf and Grass Weeds. Weed Technol. 2007, 21, 159-165. [CrossRef]

24. Hossard, L.; Philibert, A.; Bertrand, M.; Colnenne-David, C.; Debaeke, P.; Munier-Jolain, N.; Jeuffroy, M.H.; Richard, G.; Makowski, D. Effects of Halving Pesticide Use on Wheat Production. Sci. Rep. 2014, 4, 4405. [CrossRef]

25. Waryszak, P.; Lenz, T.L.; Leishman, M.R.; Downey, P.O. Herbicide Effectiveness in Controlling Invasive Plants under Elevated $\mathrm{CO}_{2}$ : Sufficient Evidence to Rethink Weeds Management. J. Environ. Manag. 2018, 226, 400-407. [CrossRef]

26. Cowie, B.W.; Venter, N.; Witkowski, E.T.; Byrne, M.J. Implications of Elevated Carbon Dioxide on the Susceptibility of the Globally Invasive Weed, Parthenium hysterophorus, to Glyphosate Herbicide. Pest Manag. Sci. 2020, 76, 2324-2332. [CrossRef] [PubMed]

27. Manea, A.; Leishman, M.R.; Downey, P.O. Exotic C4 Grasses Have Increased Tolerance to Glyphosate under Elevated Carbon Dioxide. Weed Sci. 2011, 59, 28-36. [CrossRef]

28. Jabran, K.; Doğan, M.N. High Carbon Dioxide Concentration and Elevated Temperature Impact the Growth of Weeds but Do Not Change the Efficacy of Glyphosate. Pest Manag. Sci. 2018, 74, 766-771. [CrossRef] 
29. Bajwa, A.A.; Wang, H.; Chauhan, B.S.; Adkins, S.W. Effect of Elevated Carbon Dioxide Concentration on Growth, Productivity and Glyphosate Response of Parthenium Weed (Parthenium hysterophorus L.). Pest Manag. Sci. 2019, 75, 2934-2941. [CrossRef]

30. Iqbal, N.; Manalil, S.; Chauhan, B.S.; Adkins, S. Effect of Different Climate Change Variables on the Ecology and Management of Sesbania cannabina through Glyphosate. Plants 2021, 10, 910. [CrossRef]

31. Matzrafi, M.; Brunharo, C.; Tehranchian, P.; Hanson, B.D.; Jasieniuk, M. Increased Temperatures and Elevated $\mathrm{CO}_{2}$ Levels Reduce the Sensitivity of Conyza canadensis and Chenopodium album to Glyphosate. Sci. Rep. 2019, 9, 2228. [CrossRef]

32. Ziska, L.H. Climate Change and the Herbicide Paradigm: Visiting the Future. Agronomy 2020, 10, 1953. [CrossRef]

33. US EPA. Brief Overview about Individual Pesticides. Available online: https://www.epa.gov/ingredients-used-pesticideproducts/brief-overviews-about-individual-pesticides (accessed on 25 August 2021).

34. Gervais, J.; Luukinen, B.; Buhl, K.; Stone, D. 2,4-D Technical Fact Sheet; National Pesticide Information Center, Oregon State University Extension Services: Corvallis, OR, USA, 2008. Available online: http://npic.orst.edu/factsheets/archive/2,4-DTech. html (accessed on 25 August 2021).

35. Henderson, A.M.; Gervais, J.A.; Luukinen, B.; Buhl, K.; Stone, D. Glyphosate General Fact Sheet; National Pesticide Information Center, Oregon State University Extension Services: Corvallis, OR, USA, 2010. Available online: http:/ /npic.orst.edu/factsheets/ glyphogen.html (accessed on 25 August 2021).

36. Minnesota Department of Agriculture. Dicamba-General Information. Available online: https://www.mda.state.mn.us/ dicamba-general-information (accessed on 25 August 2021).

37. Bunch, T.R.; Gervais, J.A.; Buhl, K.; Stone, D. Dicamba Technical Fact Sheet; National Pesticide Information Center, Oregon State University Extension Services: Corvallis, OR, USA, 2012. Available online: http://npic.orst.edu/factsheets/archive/dicamba_ tech.html (accessed on 25 August 2021).

38. Klementova, S.; Keltnerova, L. Triazine Herbicides in the Environment. In Herbicides, Physiology of Action, and Safety; InTech: London, UK, 2015; pp. 71-96. [CrossRef]

39. Watts, M. Paraquat. Available online: http://wssroc.agron.ntu.edu.tw/note/Paraquat.pdf (accessed on 27 August 2021).

40. Lewis, K.A.; Tzilivakis, J.; Warner, D.J.; Green, A. An International Database for Pesticide Risk Assessments and Management. Hum. Ecol. Risk Assess. Int. J. 2016, 22, 1050-1064. [CrossRef]

41. Gervais, J.; Luukinen, B.; Buhl, K.; Stone, D. Malathion General Fact Sheet; National Pesticide Information Center, Oregon State University Extension Services: Corvallis, OR, USA, 2009. Available online: http://npic.orst.edu/factsheets/malagen.html (accessed on 26 August 2021).

42. Davis, M.K.; Boone, J.S.; Moran, J.E.; Tyler, J.W.; Chambers, J.E. Assessing Intermittent Pesticide Exposure from Flea Control Collars Containing the Organophosphorus Insecticide Tetrachlorvinphos. J. Expo. Sci. Environ. Epidemiol. 2008, 18, 564-570. [CrossRef]

43. Singh, A.; Tiwari, M.; Prakash, O.; Singh, M. A Current Review of Cypermethrin-Induced Neurotoxicity and Nigrostriatal Dopaminergic Neurodegeneration. Curr. Neuropharmacol. 2012, 10, 64-71. [CrossRef]

44. Gervais, J.A.; Luukinen, B.; Buhl, K.; Stone, D. Imidacloprid Technical Fact Sheet; National Pesticide Information Center, Oregon State University Extension Services: Corvallis, OR, USA, 2010. Available online: http://npic.orst.edu/factsheets/archive/ imidacloprid.html (accessed on 26 August 2021).

45. Minnesota Department of Agriculture. Mancozeb Fungicide. Available online: https://www.mda.state.mn.us/mancozebfungicide (accessed on 25 August 2021).

46. Chowdhury, A.; Pradhan, S.; Saha, M.; Sanyal, N. Impact of Pesticides on Soil Microbiological Parameters and Possible Bioremediation Strategies. Indian J. Microbiol. 2008, 48, 114-127. [CrossRef]

47. Latchoumycandane, C.; Jenardhanan, P.; Mathur, P.P. Environmental Impact on Gametogenesis and Embryogenesis: An Overview. In Encyclopedia of Reproduction; Elsevier: Amsterdam, The Netherlands, 2018; pp. 446-451. [CrossRef]

48. Chekroun, B.; Ben Chekroun, K.; Baghour, M. The Role of Algae in Phytoremediation of Heavy Metals: A Review. J. Mater. Environ. Sci. 2013, 4, 873-880.

49. Kumar, S.; Joshi, P.C.; Nath, P.; Singh, V.K. Impacts of Insecticides on Pollinators of Different Food Plants. Entomol. Ornithol. Herpetol. 2018, 7, 211. [CrossRef]

50. Sharma, A.; Kumar, V.; Shahzad, B.; Tanveer, M.; Sidhu, G.P.S.; Handa, N.; Kohli, S.K.; Yadav, P.; Bali, A.S.; Parihar, R.D.; et al. Worldwide Pesticide Usage and Its Impacts on Ecosystem. SN Appl. Sci. 2019, 1, 1446. [CrossRef]

51. Sharma, N.; Singhvi, R. Effects of Chemical Fertilizers and Pesticides on Human Health and Environment: A Review. Int. J. Agric. Environ. Biotechnol. 2017, 10, 675. [CrossRef]

52. McDonald, T.A.; Holland, N.T.; Skibola, C.; Duramad, P.; Smith, M.T. Hypothesis: Phenol and Hydroquinone Derived Mainly from Diet and Gastrointestinal Flora Activity Are Causal Factors in Leukemia. Leukemia 2001, 15, 10-20. [CrossRef]

53. Prashar, P.; Shah, S. Impact of Fertilizers and Pesticides on Soil Microflora in Agriculture. In Sustainable Agriculture Reviews; Lichtfouse, E., Ed.; Springer: Cham, Switzerland, 2016; pp. 331-361. [CrossRef]

54. Gunstone, T.; Cornelisse, T.; Kendra, K.; Aditi, D.; Donley, N. Pesticides and Soil Invertebrates: A Hazard Assessment. Front. Environ. Sci. 2021, 9, 122. [CrossRef]

55. Lo, C.-C. Effect of Pesticides on Soil Microbial Community. J. Environ. Sci. Health Part B 2010, 45, 348-359. [CrossRef]

56. Arora, S.; Sahni, D. Pesticides Effect on Soil Microbial Ecology and Enzyme Activity-An Overview. J. Appl. Nat. Sci. 2016, 8 , 1126-1132. [CrossRef] 
57. Ripper, W.E.; Greenslade, R.M.; Lickerish, L.A. Combined Chemical and Biological Control of Insects by Means of a Systemic Insecticide. Nature 1949, 163, 787-789. [CrossRef]

58. Philippat, C.; Barkoski, J.; Tancredi, D.J.; Elms, B.; Barr, D.B.; Ozonoff, S.; Bennett, D.H.; Hertz-Picciotto, I. Prenatal Exposure to Organophosphate Pesticides and Risk of Autism Spectrum Disorders and Other Non-Typical Development at 3 Years in a High-Risk Cohort. Int. J. Hyg. Environ. Health 2018, 221, 548-555. [CrossRef]

59. Yadav, H.; Singh Sankhla, M.; Kumar, R. Pesticides-Induced Carcinogenic \& Neurotoxic Effect on Human. Forensic Res. Criminol. Int. J. 2019, 7, 243-245. [CrossRef]

60. Rocha, G.M.; Grisolia, C.K. Why Pesticides with Mutagenic, Carcinogenic and Reproductive Risks are Registered in Brazil. Dev. World Bioeth. 2019, 19, 148-154. [CrossRef]

61. Mustafa, S.; Bhatti, N.; Maqbool, M. Microalgae Biosorption, Bioaccumulation and Biodegradation Efficiency for the Remediation of Wastewater and Carbon Dioxide Mitigation: Prospects, Challenges and Opportunities. J. Water Process Eng. 2021, 41, 2214-7144. [CrossRef]

62. Hussein, M.H.; Abdullah, A.M.; Badr El Din, N.I.; Mishaqa, E.S.I. Biosorption Potential of the Microchlorophyte Chlorella vulgaris for Some Pesticides. J. Fertil. Pestic. 2017, 8, 1-5. [CrossRef]

63. Komárek, M.; Čadková, E.; Chrastný, V.; Bordas, F.; Bollinger, J.C. Contamination of Vineyard Soils with Fungicides: A Review of Environmental and Toxicological Aspects. Environ. Int. 2010, 36, 138-151. [CrossRef]

64. Sakurai, T.; Aoki, M.; Ju, X.; Ueda, T.; Nakamura, Y.; Fujiwara, S.; Umemura, T.; Tsuzuki, M.; Minoda, A. Profiling of Lipid and Glycogen Accumulations Under Different Growth Conditions in the Sulfothermophilic Red Alga Galdieria sulphuraria. Bioresour. Technol. 2016, 200, 861-866. [CrossRef] [PubMed]

65. Wang, L.; Xiao, H.; He, N.; Sun, D.; Duan, S. Biosorption and Biodegradation of the Environmental Hormone Nonylphenol By Four Marine Microalgae. Sci. Rep. 2019, 9, 5277. [CrossRef]

66. Fomina, M.; Gadd, G.M. Biosorption: Current Perspectives on Concept, Definition and Application. Bioresour. Technol. 2014, 160, 3-14. [CrossRef]

67. Sethunathan, N.; Megharaj, M.; Chen, Z.L.; Williams, B.D.; Lewis, G.; Naidu, R. Algal Degradation of a Known Endocrine Disrupting Insecticide, $\alpha$-Endosulfan, and Its Metabolite, Endosulfan Sulfate, in Liquid Medium and Soil. J. Agric. Food Chem. 2004, 52, 3030-3035. [CrossRef]

68. Ghasemi, Y.; Rasoul-Amini, S.; Fotooh-Abadi, E. The Biotransformation, Biodegradation, and Bioremediation of Organic Compounds by Microalgae. J. Phycol. 2011, 47, 969-980. [CrossRef]

69. Weis, L.; de Cassia de Souza Schneider, R.; Hoeltz, M.; Rieger, A.; Tostes, S.; Lobo, E.A. Potential for Bifenthrin Removal Using Microalgae from a Natural Source. Water Sci. Technol. 2020, 82, 1131-1141. [CrossRef]

70. Gregory, W.W.; Reed, J.K.; Priester, L.E. Accumulation of Parathion and DDT by Some Algae and Protozoa. J. Protozool. 1969, 16, 69-71. [CrossRef]

71. Kurade, M.B.; Kim, J.R.; Govindwar, S.P.; Jeon, B.H. Insights into Microalgae Mediated Biodegradation of Diazinon by Chlorella vulgaris: Microalgal Tolerance to Xenobiotic Pollutants and Metabolism. Algal Res. 2016, 20, 126-134. [CrossRef]

72. Velásquez, L.; Dussan, J. Biosorption and Bioaccumulation of Heavy Metals on Dead and Living Biomass of Bacillus sphaericus. J. Hazard. Mater. 2009, 167, 713-716. [CrossRef]

73. Dosnon-Olette, R.; Trotel-Aziz, P.; Couderchet, M.; Eullaffroy, P. Fungicides and Herbicide Removal in Scenedesmus Cell Suspensions. Chemosphere 2010, 79, 117-123. [CrossRef]

74. Encarnação, T.; Santos, D.; Ferreira, S.; Valente, A.J.M.; Pereira, J.C.; Campos, M.G.; Burrows, H.D.; Pais, A.A.C.C. Removal of Imidacloprid from Water by Microalgae Nannochloropsis sp. and Its Determination by a Validated RP-HPLC Method. Bull. Environ. Contam. Toxicol. 2021, 107, 131-139. [CrossRef]

75. Nanda, M.; Kumar, V.; Fatima, N.; Pruthi, V.; Verma, M.; Chauhan, P.; Vlaskin, M.; Grigorenko, A. Detoxification Mechanism of Organophosphorus Pesticide via Carboxylestrase Pathway that Triggers de Novo TAG Biosynthesis in Oleaginous Microalgae. Aquat. Toxicol. 2019, 209, 49-55. [CrossRef]

76. Ni, Y.; Lai, J.; Wan, J.; Chen, L. Photosynthetic Responses and Accumulation of Mesotrione in Two Freshwater Algae. Environ. Sci. Process. Impacts. 2014, 16, 2288-2294. [CrossRef]

77. Ata, A.; Nalcaci, O.O.; Ovez, B. Macro algae Gracilaria verrucosa as a biosorbent: A study of sorption mechanisms. Algal Res. 2012, 1, 194-204. [CrossRef]

78. Bilal, M.; Rasheed, T.; Sosa-Hernández, J.E.; Raza, A.; Nabeel, F.; Iqbal, H.M.N. Biosorption: An Interplay between Marine Algae and Potentially Toxic Elements-A Review. Mar. Drugs. 2018, 16, 65. [CrossRef]

79. Kabra, A.N.; Ji, M.K.; Choi, J.; Kim, J.R.; Govindwar, S.P.; Jeon, B.H. Toxicity of Atrazine and Its Bioaccumulation and Biodegradation in a Green Microalga, Chlamydomonas mexicana. Environ. Sci. Pollut. Res. 2014, 21, 12270-12278. [CrossRef]

80. Swackhamer, D.L.; Skoglund, R.S. Bioaccumulation of PCBs by Algae: Kinetics Versus Equilibrium. Environ. Toxicol. Chem. 1993, 12, 831-838. [CrossRef]

81. Pérez-Legaspi, I.A.; Ortega-Clemente, L.A.; Moha-León, J.D.; Ríos-Leal, E.; Gutiérrez, S.C.-R.; Rubio-Franchini, I. Effect of the Pesticide Lindane on the Biomass of the Microalgae Nannochloris oculata. J. Environ. Sci. Health Part B 2015, 51, 103-106. [CrossRef]

82. Qiu, Y.W.; Zeng, E.Y.; Qiu, H.; Yu, K.; Cai, S. Bioconcentration of Polybrominated Diphenyl Ethers and Organochlorine Pesticides in Algae Is an Important Contaminant Route to Higher Trophic Levels. Sci. Total Environ. 2017, 579, 1885-1893. [CrossRef]

83. Devonshire, A.L.; Field, L.M. Gene Amplification and Insecticide Resistance. Annu. Rev. Entomol. 1991, 36, 1-21. [CrossRef] 
84. Ortiz-Hernández, M.L.; Sánchez-Salinas, E.; Dantán-González, E.; Castrejón-Godínez, M.L. Pesticide Biodegradation: Mechanisms, Genetics and Strategies to Enhance the Process. In Biodegradation_Life of Science; Chamy, R., Rosenkranz, F., Eds.; InTech: London, UK, 2013; pp. 251-287. [CrossRef]

85. Xu, P.; Huang, L. Stereoselective Bioaccumulation, Transformation, and Toxicity of Triadimefon in Scenedesmus obliquus. Chirality 2017, 29, 61-69. [CrossRef]

86. Zhu, J.; Liu, W. A Tale of Two Databases: The Use of Web of Science and Scopus in Academic Papers. Scientometrics 2020, 123, 321-335. [CrossRef]

87. Linnenluecke, M.K.; Marrone, M.; Singh, A.K. Conducting Systematic Literature Reviews and Bibliometric Analyses. Aust. J. Manag. 2020, 45, 175-194. [CrossRef]

88. AlRyalat, S.A.S.; Malkawi, L.W.; Momani, S.M. Comparing Bibliometric Analysis using PubMed, Scopus, and Web of Science Databases. J. Vis. Exp. 2019, 152, e58494. [CrossRef]

89. Hood, W.W.; Wilson, C.S. The Literature of Bibliometrics, Scientometrics, and Informetrics. Scientometrics 2001, 52, 291-314. [CrossRef]

90. Moral-Muñoz, J.A.; Herrera-Viedma, E.; Santisteban-Espejo, A.; Cobo, M.J. Software Tools for Conducting Bibliometric Analysis in Science: An up-to-Date Review. Prof. Inf. 2020, 29, 1-20. [CrossRef]

91. Pedraza, S.; Clerici, N.; Gaviria, J.D.Z.; Sanchez, A. Global Research on Riparian Zones in the Xxi Century: A Bibliometric Analysis. Water 2021, 13, 1836. [CrossRef]

92. De Bakker, F.G.A.; Groenewegen, P.; Hond, F.D. A Bibliometric Analysis of 30 Years of Research and Theory on Corporate Social Responsibility and Corporate Social Performance. Bus. Soc. 2005, 44, 283-317. [CrossRef]

93. Maldonado-Erazo, C.P.; Álvarez-García, J.; Río-Rama, M.d.l.C.d.; Durán-Sánchez, A. Scientific Mapping on the Impact of Climate Change on Cultural and Natural Heritage: A Systematic Scientometric Analysis. Land 2021, 10, 76. [CrossRef]

94. Gorraiz, J.; Schloegl, C. A Bibliometric Analysis of Pharmacology and Pharmacy Journals: Scopus versus Web of Science. J. Inf. Sci. 2008, 34, 715-725. [CrossRef]

95. Md Khudzari, J.; Kurian, J.; Tartakovsky, B.; Raghavan, G.S.V. Bibliometric Analysis of Global Research Trends on Microbial Fuel Cells Using Scopus Database. Biochem. Eng. J. 2018, 136, 51-60. [CrossRef]

96. Harzing, A.-W.; Alakangas, S. Google Scholar, Scopus and the Web of Science: A Longitudinal and Cross-Disciplinary Comparison. Scientometrics 2015, 106, 787-804. [CrossRef]

97. Parlina, A.; Ramli, K.; Murfi, H. Theme Mapping and Bibliometrics Analysis of One Decade of Big Data Research in the Scopus Database. Information 2020, 11, 69. [CrossRef]

98. Asiri, F.Y.; Kruger, E.; Tennant, M. Global Dental Publications in PubMed Databases between 2009 and 2019-A Bibliometric Analysis. Molecules 2020, 25, 4747. [CrossRef]

99. Scopus. Available online: https:/ / www.scopus.com/search/form.uri?display=basic\#basic (accessed on 10 August 2021).

100. Kulkarni, A.V.; Aziz, B.; Shams, I.; Busse, J.W. Comparisons of Citations in Web of Science, Scopus, and Google Scholar for Articles Published in General Medical Journals. JAMA J. Am. Med. Assoc. 2009, 302, 1092-1096. [CrossRef]

101. Kiduk, Y.; Meho, L.I. Citation Analysis: A Comparison of Google Scholar, Scopus, and Web of Science. Proc. Am. Soc. Inf. Sci. Technol. 2006, 43, 1-15. [CrossRef]

102. van Eck, N.J.; Waltman, L. VOSviewer Manual: Manual for VOSviewer Version 1.6.7. Univeristeit Leiden. 2018, 51, 1-50.

103. van Eck, N.J.; Waltman, L. Software Survey: VOSviewer, a Computer Program for Bibliometric Mapping. Scientometrics 2010, 84, 523-538. [CrossRef]

104. Datawrapper: Create Charts, Maps, and Tables. Available online: https:/ /www.datawrapper.de/ (accessed on 18 August 2021).

105. Abdel-Razek, M.A.; Abozeid, A.M.; Eltholth, M.M.; Abouelenien, F.A.; El-Midany, S.A.; Moustafa, N.Y.; Mohamed, R.A. Bioremediation of a Pesticide and Selected Heavy Metals in Wastewater from Various Sources Using a Consortium of Microalgae and Cyanobacteria. Slov. Vet. Res. 2019, 56, 61-73. [CrossRef]

106. Contreras-Blancas, E.; Ruiz-Ordaz, N.; Galíndez-Mayer, J.; Torres-Gómez, R.E.; Arias Ruiz, A.; Juárez-Ramírez, C. Permeable Reactive Surface-Biobarriers. Testing and Evaluation of an Ecotechnology for the Removal of Agrotoxic Compounds Carried by Agricultural Runoffs. J. Environ. Health Sci. Eng. 2020, 18, 559-571. [CrossRef]

107. García-Galán, M.J.; Gutiérrez, R.; Uggetti, E.; Matamoros, V.; García, J.; Ferrer, I. Use of Full-Scale Hybrid Horizontal Tubular Photobioreactors to Process Agricultural Runoff. Biosyst. Eng. 2018, 166, 138-149. [CrossRef]

108. Nicodemus, T.J.; DiRusso, C.C.; Wilson, M.; Black, P.N. Reactive Oxygen Species (ROS) Mediated Degradation of Organophosphate Pesticides by the Green Microalgae Coccomyxa subellipsoidea. Bioresour. Technol. Rep. 2020, 11, 100461. [CrossRef]

109. Deviram, G.; Mathimani, T.; Anto, S.; Ahamed, T.S.; Ananth, D.A.; Pugazhendhi, A. Applications of Microalgal and Cyanobacterial Biomass on a Way to Safe, Cleaner and a Sustainable Environment. J. Clean. Prod. 2020, 253, 119770. [CrossRef]

110. Chaudhary, R.; Tong, Y.W.; Dikshit, A.K. Kinetic Study of Nutrients Removal from Municipal Wastewater by Chlorella Vulgaris in Photobioreactor Supplied with $\mathrm{CO}_{2}$-Enriched Air. Environ. Technol. 2020, 41, 617-626. [CrossRef]

111. Wan, L.; Wu, Y.; Ding, H.; Zhang, W. Toxicity, Biodegradation, and Metabolic Fate of Organophosphorus Pesticide Trichlorfon on the Freshwater Algae Chlamydomonas reinhardtii. J. Agric. Food Chem. 2020, 68, 1645-1653. [CrossRef] [PubMed]

112. Jalilian, N.; Najafpour, G.D.; Khajouei, M. Macro and Micro Algae in Pollution Control and Biofuel Production-A Review. ChemBioEng Rev. 2020, 7, 18-33. [CrossRef] 
113. Usmani, Z.; Sharma, M.; Lukk, T.; Karpichev, Y.; Thakur, V.K.; Kumar, V.; Allaoui, A.; Awasthi, A.K.; Gupta, V.K. Developments in Enzyme and Microalgae Based Biotechniques to Remediate Micropollutants from Aqueous Systems-A Review. Crit. Rev. Environ. Sci. Technol. 2020, 1-46. [CrossRef]

114. García-Galán, M.J.; Monllor-Alcaraz, L.S.; Postigo, C.; Uggetti, E.; López de Alda, M.; Díez-Montero, R.; García, J. MicroalgaeBased Bioremediation of Water Contaminated by Pesticides in Peri-Urban Agricultural Areas. Environ. Pollut. 2020, $265,114579$. [CrossRef]

115. Molina, D.; de Carvalho, J.C.; Júnior, A.I.M.; Faulds, C.; Bertrand, E.; Soccol, C.R. Biological Contamination and Its Chemical Control in Microalgal Mass Cultures. Appl. Microbiol. Biotechnol. 2019, 103, 9345-9358. [CrossRef]

116. Chin, Y.-Y.; Chu, W.-L.; Kok, Y.-Y.; Phang, S.-M.; Wong, C.-Y.; Tan, B.-K.; Mustafa, E.M. Sensitivity of Selected Tropical Microalgae Isolated from a Farmland and a Eutrophic Lake to Atrazine and Endosulfan. J. Appl. Phycol. 2019, 31, 2981-2998. [CrossRef]

117. Graça, C.A.L.; Maniero, M.G.; De Andrade, L.M.; Roberto Guimarães, J.; Teixeira, A.C.S.C. Evaluation of Amicarbazone Toxicity Removal through Degradation Processes Based on Hydroxyl and Sulfate Radicals. J. Environ. Sci. Health Part A Toxic/Hazard. Subst. Environ. Eng. 2019, 54,1126-1143. [CrossRef]

118. Saccà, M.L.; Ferrero, V.E.V.; Loos, R.; Di Lenola, M.; Tavazzi, S.; Grenni, P.; Ademollo, N.; Patrolecco, L.; Huggett, J.; Caracciolo, A.B.; et al. Chemical Mixtures and Fluorescence in Situ Hybridization Analysis of Natural Microbial Community in the Tiber River. Sci. Total Environ. 2019, 673, 7-19. [CrossRef]

119. Wang, X.-X.; Zhang, Q.-Q.; Wu, Y.-H.; Dao, G.-H.; Zhang, T.-Y.; Tao, Y.; Hu, H.-Y. The Light-Dependent Lethal Effects of 1,2-Benzisothiazol-3(2H)-One and Its Biodegradation by Freshwater Microalgae. Sci. Total Environ. 2019, 672, 563-571. [CrossRef]

120. Hernández-Moreno, D.; Blázquez, M.; Andreu-Sánchez, O.; Bermejo-Nogales, A.; Fernández-Cruz, M.L. Acute Hazard of Biocides for the Aquatic Environmental Compartment from a Life-Cycle Perspective. Sci. Total Environ. 2019, 658, 416-423. [CrossRef]

121. Abdel-Shafy, H.I.; Mansour, M.S.M. Phytoremediation for the Elimination of Metals, Pesticides, PAHs, and Other Pollutants from Wastewater and Soil. In Phytobiont and Ecosystem Restitution; Springer: Singapore, 2018. [CrossRef]

122. Hultberg, M.; Bodin, H. Effects of Fungal-Assisted Algal Harvesting through Biopellet Formation on Pesticides in Water. Biodegradation 2018, 29, 557-565. [CrossRef]

123. Fouilland, E.; Galès, A.; Beaugelin, I.; Lanouguère, E.; Pringault, O.; Leboulanger, C. Influence of Bacteria on the Response of Microalgae to Contaminant Mixtures. Chemosphere 2018, 211, 449-455. [CrossRef]

124. Upadhyay, A.K.; Singh, R.; Singh, D.P. Phycotechnological Approaches toward Wastewater Management; Springer: Singapore, 2018. [CrossRef]

125. Kannikka, B.; Sesha, C.P.; Subhasha, N. Bioremediation by Microalgae. In The Role of Photosynthetic Microbes in Agriculture and Industry; Nova Science Publishers, Inc.: New York, NY, USA, 2018; pp. 151-171.

126. Singh, S.; Kumar, A.; Kumar, S.P.J.; Imran, M.; Kumar, M.; Singh, A.N.; Tripathi, M.K. Bioremediation of Pesticides Residues: A Psychological Approach. In The Role of Photosynthetic Microbes in Agriculture and Industry; Keshawanand, T., Abraham, G., Eds.; Nova Science Publishers, Inc.: New York, NY, USA, 2018; pp. 209-218. [CrossRef]

127. Taştan, B.E.; Tekinay, T.; Çelik, H.S.; Özdemir, C.; Cakir, D.N. Toxicity Assessment of Pesticide Triclosan by Aquatic Organisms and Degradation Studies. Regul. Toxicol. Pharmacol. 2017, 91, 208-215. [CrossRef] [PubMed]

128. Riaz, G.; Tabinda, A.B.; Iqbal, S.; Yasar, A.; Abbas, M.; Khan, A.M.; Mahfooz, Y.; Baqar, M. Phytoremediation of Organochlorine and Pyrethroid Pesticides by Aquatic Macrophytes and Algae in Freshwater Systems. Int. J. Phytoremediat. 2017, 19, 894-898. [CrossRef] [PubMed]

129. Asad, M.A.U.; Lavoie, M.; Song, H.; Jin, Y.; Fu, Z.; Qian, H. Interaction of Chiral Herbicides with Soil Microorganisms, Algae and Vascular Plants. Sci. Total Environ. 2017, 580, 1287-1299. [CrossRef]

130. El-Sheekh, M.M.; Mahmoud, Y.A.G. Technological Approach of Bioremediation Using Microbial Tools: Bacteria, Fungi, and Algae. In Handbook of Research on Inventive Bioremediation Techniques; Bhakta, J.N., Ed.; IGI Global: Hershey, PA, USA, 2017; pp. 134-154. [CrossRef]

131. Kumari, M.; Ghosh, P.; Thakur, I.S. Landfill Leachate Treatment Using Bacto-Algal Co-Culture: An Integrated Approach Using Chemical Analyses and Toxicological Assessment. Ecotoxicol. Environ. Saf. 2016, 128, 44-51. [CrossRef]

132. Matamoros, V.; Rodríguez, Y. Batch vs. Continuous-Feeding Operational Mode for the Removal of Pesticides from Agricultural Run-off by Microalgae Systems: A Laboratory Scale Study. J. Hazard. Mater. 2016, 309, 126-132. [CrossRef]

133. Hultberg, M.; Bodin, H.; Ardal, E.; Asp, H. Effect of Microalgal Treatments on Pesticides in Water. Environ. Technol. 2016, 37, 893-898. [CrossRef]

134. Furey, P.C.; Deininger, A.; Liess, A. Substratum-Associated Microbiota. Water Environ. Res. 2016, 88, 1637-1671. [CrossRef]

135. Matamoros, V.; Gutiérrez, R.; Ferrer, I.; García, J.; Bayona, J.M. Capability of Microalgae-Based Wastewater Treatment Systems to Remove Emerging Organic Contaminants: A Pilot-Scale Study. J. Hazard. Mater. 2015, 288, 34-42. [CrossRef] [PubMed]

136. Ke, L.; Wong, Y.S.; Tam, N.F.Y. Toxicity and Removal of Organic Pollutants by Microalgae: A Review. In Microalgae: Biotechnology, Microbiology and Energy; Johansen, M.N., Ed.; Nova Science Publishers, Inc.: New York, NY, USA, 2013; pp. $101-140$.

137. Subashchandrabose, S.R.; Ramakrishnan, B.; Megharaj, M.; Venkateswarlu, K.; Naidu, R. Mixotrophic Cyanobacteria and Microalgae as Distinctive Biological Agents for Organic Pollutant Degradation. Environ. Int. 2013, 51, 59-72. [CrossRef]

138. Zhang, S.; Qiu, C.B.; Zhou, Y.; Jin, Z.P.; Yang, H. Bioaccumulation and Degradation of Pesticide Fluroxypyr Are Associated with Toxic Tolerance in Green Alga Chlamydomonas reinhardtii. Ecotoxicology 2011, 20, 337-347. [CrossRef]

139. Kumar Singh, N.; Dhar, D.W. Microalgal Remediation of Sewage Effluent. Proc. Indian Natl. Sci. Acad. 2010, 76, $209-221$. 
140. Chelinho, S.; Moreira-Santos, M.; Lima, D.; Silva, C.; Viana, P.; André, S.; Lopes, I.; Ribeiro, R.; Fialho, A.M.; Viegas, C.A.; et al. Cleanup of Atrazine-Contaminated Soils: Ecotoxicological Study on the Efficacy of a Bioremediation Tool with Pseudomonas sp. ADP. J. Soils Sediments 2010, 10, 568-578. [CrossRef]

141. Benemann, J.R.; WoertzIan, I.; Lundquist, T. Autotrophic Microalgae Biomass Production: From Niche Markets to Commodities. Ind. Biotechnol. 2018, 14, 3-10. [CrossRef]

142. Habibah, R.; Iswanto, B.; Rinanti, A. The Significance of Tropical Microalgae Chlorella sorokiniana as a Remediate of Polluted Water caused by Chlorpyrifos. Int. J. Sci. Technol. Res. 2020, 9, 4460-4463.

143. Pacheco, D.; Rocha, A.C.; Pereira, L.; Verdelhos, T. Microalgae Water Bioremediation: Trends and Hot Topics. Appl. Sci. 2020, 10, 1886. [CrossRef]

144. Ugya, A.Y.; Ajibade, F.O.; Hua, X. The Efficiency of Microalgae Biofilm in the Phycoremediation of Water from River Kaduna. J. Environ. Manag. 2021, 295, 113109. [CrossRef]

145. Raymond Sunday, E. Phycoremediation: An Eco-Solution to Environmental Protection and Sustainable Remediation. J. Chem. Environ. Biol. Eng. 2018, 2, 5. [CrossRef] 